\title{
Agile route-to-market distribution strategies in emerging markets: the case of Paraguay
}

Article

Accepted Version

Boojihawon (Roshan), D. K., Richeri, A., Liu, Y. and Chicksand, D. (2021) Agile route-to-market distribution strategies in emerging markets: the case of Paraguay. Journal of International Management, 27 (1). 100740. ISSN 1075-4253 doi: https://doi.org/10.1016/j.intman.2020.100740 Available at https://centaur.reading.ac.uk/89537/

It is advisable to refer to the publisher's version if you intend to cite from the work. See Guidance on citing.

Published version at: http://dx.doi.org/10.1016/j.intman.2020.100740

To link to this article DOI: http://dx.doi.org/10.1016/j.intman.2020.100740

Publisher: Elsevier

All outputs in CentAUR are protected by Intellectual Property Rights law, including copyright law. Copyright and IPR is retained by the creators or other copyright holders. Terms and conditions for use of this material are defined in the End User Agreement.

www.reading.ac.uk/centaur 
Central Archive at the University of Reading

Reading's research outputs online 


\section{Agile Route-to-Market Distribution Strategies in Emerging markets: The Case of Paraguay}

*Boojihawon, Dev Kumar (Roshan), Senior Lecturer in Strategy, Department of Strategy \& International Business, Birmingham Business School, University of Birmingham, B15 2TT, U.K.

d.k.boojihawon@bham.ac.uk

Richeri, Augusto, Commercial Manager Paraguay - SC Johnson, Paraguay, ARicher@scj.com

Liu, Yipeng, Professor of Management and Organisation Studies, Henley Business School, University of Reading, RG6 6UD, U.K. yipeng.liu@ henley.ac.uk

Chicksand, Daniel, Reader, Reader in Operations and Supply Management, Department of Management, Procurement and Operations Management Group, Birmingham Business School, University of Birmingham, B15 2TT, U.K., D.Chicksand@bham.ac.uk

*Corresponding author 


\title{
Agile Route-to-Market Distribution Strategies in Emerging Markets: The Case of Paraguay
}

\begin{abstract}
The intensifying presence of multi-national enterprises (MNEs) in emerging markets is of continued interest to strategy and international management scholars. In terms of theory, we know little about how proactive, agile route-to-market (RTM) decisions are made, developed and implemented to enable strategic renewal and sustainability in socio-economic contexts. Our aim in this paper is to understand the factors underpinning RTM agile capabilities, and how they influence the development of the agile distribution strategies of two competing consumer packaged goods multinational enterprises (CPG MNEs) (Mondelez International and Nestlé) MNEs in Paraguay. Drawing on the resource-based view (RBV), we examine their RTM adaptation approaches within the context of a common 'product-market venture' distribution in Paraguay. Methodologically, we use comparative case-based analysis and undertake a two-pronged approach, examining distribution-related archival data from these two MNEs, as well as interviewing 20 of their local senior managers, distributors and point-of-sale operators, in order to comprehend the market realities of the distribution-end of their value chain. Contextual influences and RTM agile managerial capabilities, particularly those rooted at micro-market levels, have strong influences on the RTM strategies of these CPG MNEs in their devising of proactive, innovative and locally aligned or relevant ways to overcome local barriers to sustaining regeneration of their competitive advantages. We end by discussing how the insights presented in this paper extend the field of research in strategic agility in international distribution in different socio-economic contexts.
\end{abstract}

Keywords: distribution, adaptation, agility, multinationals, route-to-market, Paraguay 


\section{Agile Route-to-Market Distribution Strategies in Emerging Markets: The Case of Paraguay}

\section{Introduction}

In general, multinational enterprises (MNEs) are continuing to intensify their activities and operations in emerging markets in the search for new avenues of growth. These markets are attractive, as they exhibit myriad untapped opportunities, along with a growth rate that is expected to be three times faster than that of developed economies (Bianchi, 2006; 2009; Kumar et al., 2014). In economic terms, emerging markets are characterised as "low income, rapid growth countries using economic liberalisation as their primary engine of growth" (Hoskisson et al., 2000, p.252).

Market-oriented studies add depth to this description, further asserting that (Prahalad, 2006; Welsh et al. 2006; Chen et al., 2010; Elg et al. 2017) MNEs have to navigate highly risky and uncertain, fragmented or unorganised market contexts, compelling them to respond creatively to institutionally weak, geographically diverse, fiercely competitive and rapidly changing socioeconomic contexts if they are to succeed (Forteza, 1997; Coe \& Lee, 2013; Cuervo-Cazurra, 2016; Aguilera et al. 2017; Surdu et al. 2018). Given these characteristics, doing business in these markets therefore poses a serious challenge to the international management approaches that MNEs might adopt (Fourné, 2012). Anecdotal evidence suggests that MNEs have recognised their lack of strategic and operational ability at grasping opportunities effectively in these markets, and that where they have succeeded, they have had to be proactively agile in rethinking how to adapt and compete at grassroots level (Accenture, 2014). However, theoretically and empirically, we know little about how these adaptive processes and underpinning agile management practices unfold in emerging markets (Johnston, 2009; Lee \& Xia, 2010; Lu \& Ramamurthy, 2011; Fayezi et al. 2017); understanding these practices is our concern here.

Much of what we know about the adaptation strategies of MNEs in international management is very generic or industry specific, and based around debates on standardisation or adaptation (e.g., Levitt, 1960; 1983; Walters, 1986; Yip, 1989; Szymanski et al., 1993; Tan and Sousa, 2013). Here we argue that, although useful, these studies fall short of providing insights into how local market dynamics affect the adaptation strategies of MNEs (Teece et al. 2016). To understand this aspect, research needs to progress deeper, to RTM levels, in order to understand how firm behaviour unfolds at grassroots or micro-market levels, and how firms are urged to stay 'agile' and persevere with their efforts to constantly develop, reconfigure, and stretch their resources and capabilities at remaining nimble and competitive (Vendrell-Herrero et al., 2016). The ways in which these decisions are made and developed on the ground, and how they affect firm performance, remain an intriguing and under-researched area in international management (Shams 2016; Ferraris et al. 2017; Pereira et al. 2018; Del Giudice et al, 2018; Adomako et al., 2019).

Theoretically, we know that being agile relates to a firm's inner capacity to be infinitely, strategically flexible and adaptable, without having to change or compromise its efficacy. Such capacity might be very dispersed in MNEs, and in marketing and distribution this capacity might be localised at the level of individual distribution managers and teams, distribution partners and 
individual vendors who are at the forefront of local market dynamics (Dyer and Shafer, 1998; Fleury et al. 2013). Agility, here, might be demonstrated in the ability of distribution specialists, managers and vendors to quickly detect market and competitive changes, opportunities, and threats (alertness), quickly access relevant data (accessibility), make resolute decisions about how to act (decisiveness), quickly implement those decisions (swiftness), and modify their range of distribution tactics and operations to the extent needed, in order to implement the strategy effectively and flexibly (Weber and Tarba, 2014; Junni et al, 2015; Fayezi et al. 2017; Liu et al. 2019). Therefore, the manifestations of agility are largely dependent on how "route-to-market or distribution" managerial capability is embedded within an MNE's international strategies.

Whilst we know little from an international management perspective (Johnston, 2009; Elg et al. 2017; Collinson \& Liu, 2018), the notion of strategic agility (Doz \& Kosonen, 2008 a, b; Weber \& Tarba, 2014) has received a fair amount of attention in strategy literature. Extant research sheds light on how large and established incumbent organizations continuously regenerate their competitive advantage by infusing innovative ideas into their strategies as a response to external uncertainty and turbulence, while aiming to act on new opportunities (Weber \& Tarba, 2014; Junni et al. 2015; Ivory \& Brooks, 2017). In particular, however, there is a lack of empirical evidence examining how firms enact and develop agile decisions at micro-market levels when dealing with continuous change and uncertainty (Doz \& Kosonen, 2008a; Bianchi \& Saleh, 2011; Fourné, 2012; Cuervo-Cazurra, 2016; Adomako et al. 2019). This paper aims to fill this theoretical gap by attempting to show how CPG MNEs exercise greater agility in the unorganised distribution context of Paraguay. We use the following research question to guide our purpose:

\section{How do RTM agility capabilities influence MNEs' adaptation of RTM strategies in emerging economies, in this case Paraguay?}

This study makes three important theoretical contributions to research at the intersection of international management and strategic agility. First, by juxtaposing the literature streams on resource-based view and strategic agility, it provides a nuanced understanding of agility in international management, suggesting it to be a managerial, RTM, agility capability, albeit seen from an international distribution perspective. Second, our findings highlight the roles played by the regional distribution strategies of MNEs - either standardization or adaptation strategies - in triggering and directing how agile RTM managerial capabilities, tactics and strategies are enacted at micro-market levels. Third, we contribute to strategic agility research in emerging markets, also recognised as under research socio-economic contexts, by examining the roles played by local, micro-stakeholders when carrying out RTM strategies.

The rest of the paper is organized as follows. We begin by reviewing and discussing the current adaptation literature from an international management perspective, with particular focus on emerging markets. We augment this by reviewing and drawing theoretical insights from the resource-based view (RBV), dynamic capabilities, strategic agility and micro-foundation literature to inform the theoretical framework underpinning our research question. We then present the research context and methodology. Next, we discuss our empirical findings. We conclude by proposing an empirically-extended, resource-based RTM agility model, and outline its theoretical and managerial implications, as well as possible future research directions. 


\section{Literature Review and Theoretical Framework}

\section{Theoretical background}

\section{Adapting and managing international distribution}

Standardization or adaptation of international distribution is a key consideration within an MNE's international strategy, and directly affects its pathway in international expansion (e.g., Elinder, 1961; Boddewyn et al., 1986; Murray et al. 2012; Szymanski et al., 1993; Coe \& Lee, 2013). In its simplest form, distribution constitutes the chain of all the business and related activities that a firm undertakes to reach its end consumer (Bucklin et al., 2008). During international distribution, this process becomes more elaborate and possibly more sophisticated, illustrating a multitude of localised RTM strategies that companies can deploy to reach their end consumers (Douglas and Wind, 1987; Ghoshal, 1987; Yip, 1989; Förster et al., 2014). Adaptation of international distribution activities therefore makes common business sense, as every market exhibits its own unique traits, which prompts the need to adapt in order to find the most effective routes to reach the end consumer in the respective target markets (Vendrell-Herrero et al. 2017; Sinha \& Sheth, 2017; Mellahi et al., 2010). Tan and Sousa (2013), however, argue that we know little about the adaptation of international management variables (e.g. distribution activities), as they remain too fragmented with unclear insights at local granular RTM levels, particularly when we consider the rapidly developing, unorganized, and uncertain territories of the emerging markets (Murray et al. 2012; Fourné, 2012). In sum, there is a need to understand how the international adaptation of distribution unfolds in these contexts (Theodosiou and Leonidou, 2003; Sheth, 2011; Liu and Vrontis, 2017). Next, we argue the case for using the theoretical lens of 'agility' to understand how micro-managerial processes unfold at RTM levels in these contexts.

\section{The need for RTM agility: developing a resource-based theoretical framework}

From a Resource-Based View (RBV), and particularly a dynamic capabilities perspective, developing strategic agility capabilities is an ongoing concern for organizations of all types and sizes, but particularly those that see themselves as innovative and entrepreneurial as they strive to stay ahead, fresh, nimble, and responsive to continuous change in different market contexts (Barney, 2001; Junni et al., 2015; Teece et al, 2016). Theoretically, the concept of "strategic agility" has received much attention from strategy and management scholars (Doz and Kosonen, 2008a, b; Yves \& Kosonen, 2010; Weber and Tarba, 2014). To them, strategic agility is primarily knowledge-based, and depends on a proactive management approach that focuses on synthesizing information and understanding how to anticipate changes in the business environment, i.e., dynamic capabilities (Fourne et al., 2014; Liu \& Vrontis, 2017). A review of international retailing management literature suggests that a proactive and agile retailer can be successful through its capabilities of responsiveness, competence, flexibility and speed in achieving or regenerating competitive advantage (Frazier, 1999; Ghauri et al., 2008; Khoshnood and Nematizadeh, 2017). Agility is also directly dependent on the speed or swiftness with which the firm is able to produce and distribute new products and manage costs effectively, whilst remaining entrepreneurially relevant to local market conditions (Boojihawon et al. 2007; Junni et al. 2015). 
Generally speaking, whilst emerging markets remain attractive territories for MNE business growth, our understanding of empirical progress with relation to how strategic agility is enacted within and across these complex organizations, and the managerial issues involved, is still at an early stage (Adomako et al. 2019). The works of Fourné (2012) and Fourné et al. (2014) have begun to provide a compelling argument as to why this subject deserves further scholarly attention from a dynamic capabilities' perspective. Fourné et al assert that: "complex organisations (like MNEs) set in increasingly dynamic business environments need to be strategically agile to stay at the frontier of market, technological, and regulatory developments. Strategic agility is even more crucial for MNEs in emerging markets due to higher levels of environmental dynamism and unpredictable market developments" (Fourné et al., 2014 p. 98). This is further supported by more recent arguments from Liu and Vrontis (2017), who posit that these markets exhibit high levels of volatility and uncertainty, as their retailing dynamics are continually changing. As such, the ability of MNEs to capture opportunities depends on their strategic agility capabilities, that is, on how quickly they are able to adapt their RTM strategies, learn on-the-go from the ground up, and be flexible in responding to the needs of both existing and new customers in those markets. We assert that such strategic agility capabilities are, in turn, reflected in dynamic local managerial capabilities with knowledge and skill at sensing market dynamics, leverage and appropriate value capture accordingly. Arguably, the latter is less understood in agility research (Whittington, 2006; Morton et al. 2018). While existing literature on agility produces insights that can help organizations achieve strategic agility, the role that key managers or individuals play in enacting and enabling the strategic agility process is under-researched. Hence, we argue that the theoretical views underpinning dynamic strategic agility capabilities provide a robust theoretical lens to aid further understanding of how international distribution strategies can unfold at firm and granular market levels, and identify the roles of RTM agility capabilities (here, captured in terms of sensing, leveraging, appropriating) act as antecedents in enabling MNEs' distribution strategies in emerging markets.

A consideration of RBV also allows us to draw on and integrate the theoretical lens of the microfoundation perspective, which analyses strategic topics, examining their foundations rooted in individual actions and interactions (Molina-Azorin, 2014). We assert that a nuanced and micromarket level understanding of individuals (stakeholders), their behaviours, actions and their social interactions in organizations can be instrumental in explaining 'agility' at RTM level, and its effects on macro-level outcomes (Liu et al. 2017). The micro-foundation lens provides a way to grasp the human behaviours, actions, skills and social interactions at play at micro-market levels, potentially adding to our understanding of the issues, processes, tactics and outcomes of RTM strategies (Barney \& Felin, 2013). Through this approach, we argue, it is possible to examine in more detail the contextual issues emerging at grassroots levels, and the human mechanisms working to determine RTM tactics and strategies (Felin et al., 2015).

We place these theoretical views into a theoretical framework, Figure 1 below, to guide with our research question and show how CPG MNEs adapt their RTM strategies and stay agile when responding to new market opportunities and uncertainties in Paraguay. From a RBV, Figure 1 argues that a CPG MNE's RTM strategy in an emerging, unorganized, retailing context is the outcome of multiple adaptation influences that emerge at ground level, and which often demand simultaneous attention when tailoring appropriate RTM strategies. The circular shapes posit that RTM decisions are iterative in nature, where managers are learning on-the-go and continually 
reviewing and revising their RTM tactics and strategies at micro level, based on information and knowledge gained from two sources. One is from interpreting local market conditions from the ground up (that is, the push factors); the other is from accommodating the pressures of integrating a global standardized distribution strategy from the MNE's headquarters (HQ) or its corporate context (that is, the pull factors) (Ozomer et al. 1991; Kumar et al. 2014). In the MNE context, therefore, the 'ideal' RTM approach, eventually, is an agile response to volatility and uncertainty around emerging markets, and the need to be aligned with MNEs' HQ desire for standardization, coherence, accountability, and control, and eventually how its global distribution strategy is deployed (Ozomer et al. 1991; Quester \& Conduit, 1996; Fourné, 2012) in consideration of overall local socio-economic conditions (Sheth, 2011; Kumar et al. 2014).

Figure 1 : A resourced-based RTM agility model for adapting international distribution

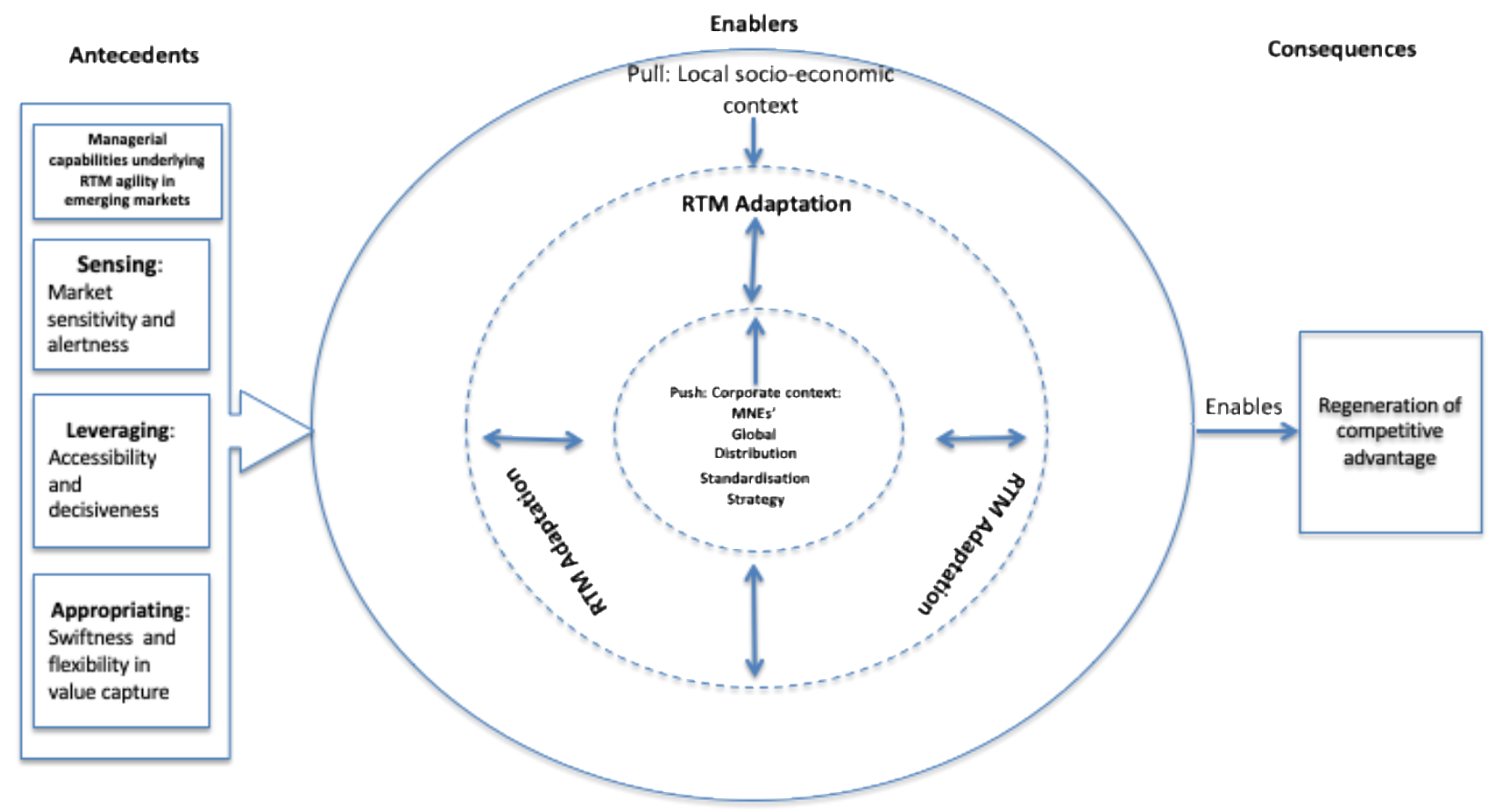

Between the push and pull influencers of HQ and local market conditions, we characterize a theoretical space where adaptation of international distribution is enacted. This space represents an ongoing interaction, negotiation and thinking between the corporate context and local stakeholders (e.g. ground-level managers, distribution partners, salespeople, and other micro-level actors and distributors) in defining and refining the shape, content, and direction of RTM strategies. We assume that the strategic goals of the 'globally standardized distribution strategy' of the corporate HQ might be based on broad-level regional economic data and market characteristics, rather than on input from local managers, distribution stakeholders, and field operators, from the ground up, who may be better connected with the realities of local customers' needs and the optimal distribution routes needed to reach them (Cespedes, 1988; Craig et al. 2011). If it ignores the latter, corporate HQ can misguide the alignment between home and host country RTM strategies and operations, or suggest RTM approaches that will not work on the ground. On the other hand, we also assume that corporate HQ may resist altering their strategic goals, as that 
would give them less control (Rao-Nicholson \& Khan, 2017). Thus, enabling this debate and improving the quality and effectiveness of RTM strategies and their execution depends on how the dynamic strategic agility capabilities, which we aver are 'the antecedents', are integrated into this theoretical space, and how we capture their contributions to regenerating competitive advantage in emerging markets (Liu et al. 2016; Sinha \& Sheth, 2017).

The next section provides further insights into the research context and methodology of this study, before deliberating on its key findings and their implications.

\section{Methodology}

\section{Research Context: the rationale for choosing Paraguay}

The retailing environment in emerging markets has undergone exponential growth and profound changes over the past 15 years, and Paraguay's retail context is illustrative of that. A 2030 market foresight report by the ATKearney Consumer Index notes that emerging markets' share of global retail sales jumped from 32 percent in 2000 to 51 percent in 2015, outpacing the rate of growth of retailing in developed markets (Ben-Shabat et al., 2018). The same report also highlights that multinational retailers have struggled to expand in these markets. The retailing environment in emerging markets can thus be a real challenge for MNEs to navigate (Samiee, 1993; Sheth, 2011; Candace et Kalliny, 2012), and can have a direct effect on customer loyalty, profitability and even on their ability to expand.

In Paraguay, many factors can explain this, such as local institutional restrictions on foreign ownership, which can urge foreign firms to either partner with local firms, or operate expensive franchises that restrict their flexibility and autonomy in expanding their businesses. Retailers are also limited by under-developed real estate and logistics infrastructures, scarcity of local talent, complex and fragmented local consumer behaviour and culture, poorly developed institutions, and in some locations even government censorship of advertising content (Hutchinson et al., 2009; Ben-Shabat et al., 2018). These issues are common restrictions MNEs have to navigate in many emerging markets. Most importantly, designing a physical distribution system in these markets requires continuous adjustments, because market, competitive, and transportation conditions are constantly changing (Theodosiou and Leonidou, 2003). These conditions reiterate Szymanski et al. (1993), Alexander and Doherty (2010) and Rao-Nicholson \& Khan's (2017) call for additional empirical studies examining the desired degree of standardization or adaptation of international strategies (including distribution channel management and sales point tactics) at grassroots market level.

Kumar et al. (2014) put forward the concept of "unorganized retailing" (which they also refer to as Traditional Trade (TT)) in emerging markets as a widespread and perhaps the most distinguishing and complex feature of their retail environment (Diaz et al., 2007; Coe \& Lee, 2013). Unorganised retailing is a consistent across the retailing environments of most of Latin America. For example, unorganized retail represents 64 percent of the total in Brazil, 80 percent in China, 95 percent in India, and 88\% in Paraguay (CCR Paraguay, 2017). Unorganized retailers 
tend to be small, diverse, and largely informal. Unorganised retailing can take many forms, but mostly consists of an informal agglomeration of several small stores owned independently and stocking a relatively small number of products. Examples include traditional store formats like family-run stores, grocers, and street vendors (Coe \& Lee, 2013; Kumar et al. 2014). Out of total retail sales in emerging markets (consumer goods products), the unorganized retailing channel accounts for a large proportion of sales, and differs greatly in comparison with developed countries, where retail environments are relatively more organised (also known as also known as Modern Trade, (MT)). We will now look at the context of Paraguay in more detail.

As an emerging market, Paraguay is one of the fastest growing economies in Latin America (Deloitte Paraguay, 2016), and serves as a good proxy for similar markets in the region (Aguilera et al., 2015). It represents a burgeoning group of rapidly growing emerging economies with similar market characteristics, retailing challenges and prospects. These include Bolivia, Guatemala, Ecuador, Peru, Columbia, Costa Rica and more widely, Bangladesh, Egypt, Ethiopia, Indonesia, Kenya, Nigeria, Pakistan, Philippines, Vietnam (Pfeiffer, 2016.). Arguably, these emerging economies are similar not just in their patterns of real GDP growth rates but, more importantly, in terms of the rapid social, lifestyle changes that result from, and help further create, the conditions for growth in these markets. This also reflects the fact that many of these markets continue to change more quickly than expected, as they transform into majority middle-class markets with mega-urbanisation trends, growing disposal incomes, young populations and more socially and technologically connected consumers, largely in the context of "unorganized" retailing environments (Forteza, 1997; Bianchi, 2006; 2009; Bianchi et al. 2011; Candace et Kalliny, 2012).

Geographically, the Republic of Paraguay lies at the centre of Latin America. It is landlocked, and bordered by Bolivia, Brazil, and Argentina. Despite its Latin American setting and being a small economy, Paraguay has a privileged geographical position, partly due to a significant fluvial system and being at the intersection of international routes and highways (CCR Paraguay 2017). This geographical position allows for easier access to the main ports and markets of South America. Paraguay, together with Brazil, Argentina, Venezuela, and Uruguay, form MERCOSUR, the largest commercial bloc in the region, a market with 290 million potential consumers (Deloitte Paraguay 2016). Therefore, Paraguay is a country with a great deal of potential for CPG manufacturers; but it also has a uniquely challenging retailing environment that hinders geographical access and distribution of CPG in a profitable manner. Paraguay is a large country $\left(406,752 \mathrm{~km}^{2}\right)$ that has high average temperatures, low population density (16.9 inhabitants per $\mathrm{km}^{2}$ ), very low average income per capita, and an official native language called Guarani, which is used predominantly in rural areas and restricts market accessibility. These are some issues CPG MNEs in Paraguay must resolve when implementing their distribution strategies, in order to develop their businesses in Paraguay (Deloitte Paraguay, 2016). This situation has influenced our methodological approach.

\section{Method}

The research question underpinning this study is a relatively unexplored topic that warrants a qualitative research strategy (Yin, 1994). Case study methodology has been used, as it allowed us to study the CPG MNEs in their natural retail distribution industry environments and obtain rich insights into the complex organisational and contextual influences underpinning the RTM 
approaches (Mouton, 1996). Additionally, case studies have been recognised as being particularly useful for examining the strategies of firms in other African (Gomes et al. 2011; Gomes et al. 2012) and emerging economies (Hoskisson et al., 2000; Hutchinson et al., 2006; Bianchi 2006, 2009 and 2011; Vahlne \& Jonsson, 2017). These studies have used multiple cases to illustrate the value of establishing a replication logic through their systematic analyses, noting significant, interesting or novel patterns that in turn enable theory building (Welch et al. 2011), and we attempt to do the same. Further, in selecting our cases we follow a similar approach to these studies and focus on a specific "product-market" venture (here, "biscuits" distribution) as our unit of analysis of CPG distribution in Paraguay (Poulis et al. 2013). More specifically, we adopt the advice of Theodosiou and Leonidou (2003), who recommend that detailed empirical studies of standardization/adaptation should be focused on and grounded in the realities of local market and industry conditions (i.e. bottom-up), rather than taking a corporate view of how these processes are developed. These authors argue that corporate-level studies only provide a limited a view of standardization/adaptation strategies, and that they might be detached from market realities and provide confusing insights. They suggest that future studies should concentrate on the "productmarket venture" level, which entails examination of the marketing of a single product line in a specific market abroad. In the present study, we take this advice on board to focus on one particular "product-market" venture ("biscuits") in "Paraguay", for two CPG MNEs, Mondelez International (MDLZ) and Nestlé (NESN), as comparative case studies of distribution strategy within the same product-market venture (Gerring, 2007; Poulis et al., 2013; Fairfield, 2015). Next, we detail the sampling and data collection process underpinning this study.

We collected our primary and secondary data as part of a broader research project on route-tomarket agility in the CPG sector in Paraguay. Connections and access to respondents were made possible and coordinated by one of the authors, who has been a senior commercial manager and with over 15 years' field experience developing effective RTM strategies for CPG MNEs in Paraguay. His work has consisted of finding agile and innovative ways to reach isolated or remote areas, with points of sale that have low purchasing power within the largely unorganized retail context of Paraguay. These practical experiences, observations, and connections not only enrich this study, but help in collecting interviewees using a snowballing strategy. The key principle underlying the selection of cases was relevance rather than representativeness (Stake, 1994; Perry, 2000; Mort \& Weerawardena, 2006). We conducted 20 in-depth interviews (lasting 30-90 mins each) between January 2017 and January 2018. Throughout the data collection, we sought to discuss the views and observations of a diverse set of senior distribution managers and distributors, each offering different views and perspectives. This is in line also with Rees and Edwards (2009) and Jamshed (2014), who suggest that interviewing multiple interviewees from different angles around the same RQ produces an assessment with a broader perspective (see also, Gomes et al. 2011; Gomes et al. 2012; Hutchinson et al., 2006; Bianchi 2006, 2009 and 2011). We ended the primary data collection at 20 interviews when additional ones did not engender significant new insights with respect to our research question. Table 1 displays informants included in this study in a role-ordered matrix (Miles et al., 2014). The interviews were recorded and transcribed, and for reasons of confidentiality, all respondents are anonymous.

The criteria measuring strategic agility strategy and management research varies depending on the subject domain of the research. Shin et al. (2015) provides a systematic review of these criteria by subject domains and conclude with two broad categorisations of agility-based studies. On the one 
hand, the regroup studies which measure 'agility' as an externally focused generic capability which prompts and support a firm to adjust its operations quickly in coping with volatile market conditions (Braunscheidel and Suresh, 2009). The other category portrays agility not as a capability, but an integrated strategy built around multi-dimensional capabilities (Dyer and Shafer, 1998; Sharifi and Zhang, 1999; Yusuf et al., 1999; Cao and Dowlatshahi, 2005; Li et al., 2008; Brannen and Doz, 2012). In a few words, these studies argue that agility should be reflected in a firm's operations; it should be nimble enough to reconfigure its overall strategy to be responsive and adaptable to environmental changes. The latter perspective on agility is more appealing to this study as it lays emphasis on the adaptive behaviour and capability that can be embodied holistically in products, services, processes, technology, or management practices (Daft, 1978, p. 197). Accordingly, we draw on this view of strategic agility and understand it as a firm's approach to achieve agile RTM strategies which are driven by the management emphasis on improving its responsiveness and adaptability to RTM needs and requirements. We operationalize this perspective by forming strategic agility as a second order factor, reflected within three underlying capabilities, as described below, and we developed our interview questions explore the micro-level issues around the RTM agility:

- $\quad$ Sensing, which alludes to heightened market sensitivity, alertness, and response to market dynamics in emerging countries at RTM levels (Weber and Tarba, 2014). Examples of questions we asked our interviewees included: How do you discover, stay alert to or quickly detect changes in your market? How do you bring in or adapt unforeseen/unplanned market-related changes or demands?

- Leveraging, which alludes to accessibility and decisiveness around resource allocation and exploiting complementarities at RTM level (D'Andrea et al. 2010; Zhang et al., 2010). Examples of questions we asked our interviewees included: How do you gain access to relevant information, and share and leverage that information to enable relevant decisions to be made based on it? How do you make those decisions quickly within your own organizational context, such as getting leadership unity and consent: convincing your superiors, overcoming hierarchy etc.

- Appropriability, which alludes to speed of thinking and action at RTM level, imbued by flexibility in value capture, as well as speed and flexibility at responding to sensed changes in the markets (Ojha, 2008; Fourné, 2012; 2014). Examples of questions we asked our interviewees included: How do you go about implementing these decisions quickly to achieve relevant fit in local markets?

- Please see Appendix 1: Table 1- Profile of Interviewees

We also developed further questions to capture the contextual situation and industry-specific factors relevant to Paraguay and its unique CPG distribution context. In parallel, we drew on additional secondary archival data (Welch 2000) such as company annual reports, industry analyses, media articles in the national and international press, and governmental documents, to triangulate our data analysis. To analyse the interviews, we used a thematic analysis process (Spiggle, 1994; 1998) to assist with categorisation and interpretation of our data, which resulted in inferences that were used to generate insights and connections to our RQ. Following Spiggle's advice on qualitative data manipulation, open, axial and selective coding was used to extract relevant themes. We then followed a manual and iterative process of categorization, abstraction, 
comparison, dimensionalisation, integration, iteration, and refutation. This process did not necessarily follow an ordered or sequential pattern, so we used NVivo 9 to facilitate organization of the data; we observed some recurring patterns and emerging themes, which helped us construct a narrative to hang our analysis on and ensure the overall qualitative analytical process was trustworthy (Sinkovics and Alfoldi, 2012). Through these qualitative analytical operations, we organised the data, extracted meaning, reached conclusions, and generated or confirmed conceptual or empirical themes and theories that describe data, consistent with Eisenhardt (1989) and Gioia. et al (2013). Also, consistent with Gomes et al. (2012), the comparative case analysis helped in noting the similarities and differences between the cases, whilst preserving the uniqueness of each case. Importantly, our research aims to illuminate some examples of replication logic, which could lead to further scholarly investigation and theory-building (Bianchi, 2009; Welch et al. 2011; Gomes et al. 2012; Gioia et al 2013).

\section{Findings}

Accordingly, we have structured the findings by consolidating data first from archival analysis (Welch, 2000) and then from our qualitative interviews. The archival analyses of data from both companies helped in contextually mapping out the generic RTM models adopted in the context of Latin America by each MNE, and how these were further adapted in the context of Paraguay, as explained below. The interview data complements this understanding, offering a more granular perspective of the influences, motivations and structures underpinning RTM strategies through the lens of agility and the detailed points of views of their CPG MNEs' local managers, distributors, and vendors.

\section{Archival analyses: Comparing the generic distribution models of Mondelez International (MDLZ) and Nestlé (NESN) - Latin American and Paraguay}

Both these MNEs adapted their distribution strategies in Paraguay, albeit using different approaches. To start with, they each worked from a standardized regional direct distribution strategy using the modern trade (MT) channel. Underlying this standardized distribution strategy is a pan-Latin American distribution model (encompassing Chile and Argentina), which recognizes that points of sale are fragmented, and that direct distribution is only successful through exclusive distributors and wholesalers with strong ground-level presence and knowledge of retailing environments. Later, we note that, in separate interviews, both CPG MNEs' managers described this as the "Argentinian distribution model" in the region, informing a distribution model that can be assumed to be the "standard" for Latin America. This implicitly implies that, for our CPG MNEs, even this "standard" distribution model has already been significantly adapted to achieve a strategic and operational fit for Latin American contexts (Quelch and Hoff, 1986; Onkvisit and Shaw, 1987; Jain, 1989; Cavusgil and Zou, 1994; Theodosiou \& Leonidou, 2003; Liu et al 2016; Rao-Nicholson \& Khan, 2017).

Two observations are pertinent to this regional "standard" RTM strategy's ability to work in Paraguay: first, we note that it relies heavily on the high-level local infrastructural, networking and knowledge-based capabilities that are expected, or even required, of a distributor working as an MNE distribution partner. MDLZ, for instance, evaluates 40 variables before considering the 
viability of a distributor, in all cases depending on a minimum score sheet of 40 requirements as acceptable. The most relevant criteria include: track record and experience, working capital enabling two months' worth of inventory, guarantees, logistics infrastructure, vehicles, information systems, and strategic alignment. In case it is not an exclusive distributor, a managerial structure, sales force, and merchandising service must be exclusively assigned to MDLZ. These requirements imply that, in all cases within the standard model, indirect distribution must be carried out with a few large, professional, and financially stable distributors with an established history of success in the market (a characteristic which we note applies to Nestlé strategy as well) (Nandonde \& Kuada, 2016). Second, we also note that "direct distribution" via the MT route in Paraguay covers only the sales equivalent of 12 percent of the whole market in the country, which is in contrast to the cases of Chile or Argentina, where the same route yields about 50-75 percent of the market (CCR Paraguay, 2017). This weak impact of the MT route for biscuits on Paraguay (amounting to accessing 168 stores across the country) leaves a huge proportion (88 percent) of this largely 'unorganized' market to be covered by informal and uncertain TT routes (Diaz et al., 2007). This realization has a profound impact on how the MNEs' RTM strategies reflect agility in adapting to further stretch, and deepens their reach to Paraguayan end consumers (Coe \& Lee, 2013; Sinha \& Sheth, 2017). Using the same set of archival data, we next further map out and contrast the RTM models of MDLZ and NESN for Paraguay.

In Paraguay, MDLZ and NESN apply two distinct RTM distribution strategies. Both are effective, but each have been moulded by different push and pull influences during their development. Figure 3 below compares the models at a structural level (CCR Paraguay, 2017), and also identifies other competing MNEs in the CPG sector that share the same model at a more generic level.

- MNEs using Model (A) have direct distribution in MT and indirect distribution by territorial distributors (TD) and wholesalers (WHs) in TT.

- MNEs using Model (B) have 100 percent indirect distribution by one master distributor (MD) for the whole country.
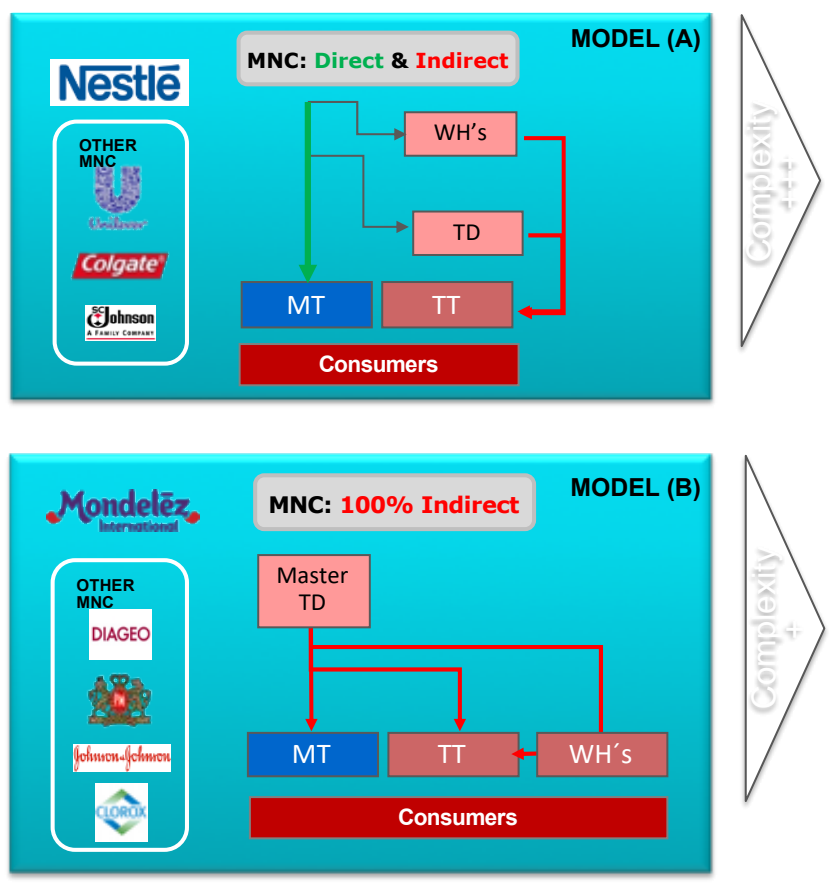

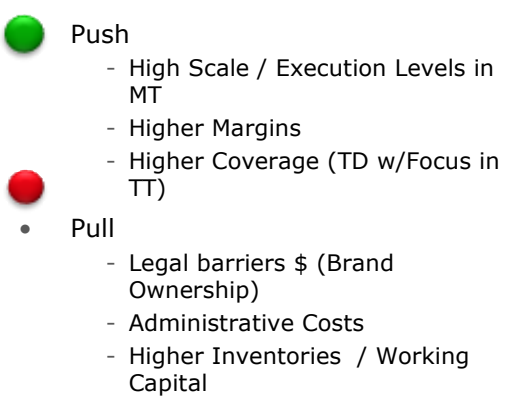

\footnotetext{
Push

- Minimize Business Complexity

Pull

- High dependence on TD'S

- Lower Margins

Portfolio Focus

Information
} 
Figure 2 - MDLZ's and NESN's Route to Market Models in Paraguay.

The main push and pull factors underpinning both models are summarized in Figure 3. Model A bears a closer resemblance to the standard "Argentinian distribution model" mentioned at the start of this section. Model B, however, represents a bolder adaptation approach, as MDLZ releases the direct control of its distribution to its master territorial distributors (MTD) who, in turn, organise its entire distribution value chain. This is due to a search for simplification by MDLZ, a need to overcome local institutional and legal barriers, rather than searching for optimization of distribution using the traditional channel. The model has its strengths and limitations. On the one hand, the use of a MTD simplifies and facilitates the distribution process, particularly in the early stages where MDLZ is unfamiliar with the market. Although this implies a reduction of the gross margin for the MNC, it ends up significantly simplifying the operative part of the business, since the MTD takes on the responsibility for tasks such as importation of goods, and sanitation (with their respective associated costs). Doing business via the MTD, however, has a significant impact on the MNE's profit margin, provides inadequate market coverage, and requires careful negotiation; it also prompts more agile ways to reach the CPG end consumer in emerging markets, where the MTD might not have a presence or be in favour for business, as with the use of more TT routes.

Further, we note from archival analysis that this reliance on TT makes the process of managing the RTM strategies highly informal and fluid (Coe \& Lee, 2013; Nandonde \& Kuada, 2016). It is continuously changing and unpredictable because of factors such as invariably increasing selling costs in a variety of CPG sectors, the influence of inventory on the role of intermediaries, the everincreasing power of supermarket chains, ground-level partnerships between manufacturers/distributors/user-customers becoming more technology-based, and other innovative forms of channel entities (like micro-vendors) emerging and offering better valueadded services for breaking bulk and offering timely local deliveries (Coe \& Lee, 2013; Sinha \& Sheth, 2017). Unorganized retailing in Paraguay thus exerts continuous pressure on MDLZ and NESN standardised approaches to distribution, and stimulates the need to display more agility in how they address these issues at ground level in order to reach their customers, stay relevant and remain profitable. We next examine the interview data to add further richness to this understanding from an agility perspective.

\section{RTM Agility in action in Paraguay}

To gain a more grassroots insight of how RTM agility unfolds, we now look at the evidence from the interview datasets around each of the key theoretical constructs underpinning RTM agilities and strategies. Appendix 2: Table 2 illustrates some supporting evidence for these key constructs, which allows us to make the following observations:

\section{'Enablers': Unravelling contextual influences on RTM Strategies}

Our evidence suggests that there are various types of local contextual influences affecting the ways in which RTM strategies are defined and adapted. Based on the literature, in our theoretical framework we noted that these can emerge broadly from these markets' local contexts. Whilst this is only a vague theoretical assertion, our empirical evidence adds further character to the kinds of adaptation influences that can impact on the RTM strategy of the CPG MNEs. With regard to local 
socio-cultural context, local institutional context and local channel structure and infrastructure context we highlighted in Figure 1, we can further delineate four other types of distinct adaptation influences at micro-market levels, namely regional, market segment-based, institutional, and distribution infrastructure-based adaptation influences. Table 2 illustrates some supporting excerpts describing these influences in more detail. These influences, theoretically, summed up as 'enablers', mould the shape and content of the appropriate RTM strategy of NESN and MDLZ, but, more particularly, provide important direction as to how they could go about adapting their regionally standardised distribution strategy for Paraguay.

\section{'Antecedents': agile managerial capabilities underlying RTM agility}

Sensing: One of the managers engaged in biscuit distribution in Paraguay described being agile almost as a norm if they are operating successfully in this market context: "...if what constitutes agility is decisiveness, swiftness, and flexibility, then I think this explains our strategy... there are many consumer goods companies in Paraguay which in the last 15 years have kept their RTM the same as it's always been, nice and unchanged, while we adjust the zone's focus and reduce the distributor size constantly to get closer to our market...the positive results speak for themselves (Interviewee 20). The dynamics of markets and competitors are uncertain and volatile, and demand that companies in the sector are continuously alert to changes in their market focus, in order to make the most of new opportunities or simply extend their reach. For instance, one of the interviewees commented that: "It's such a small market that any change in our competitors or clients is old news within 15 days or less ... When Bauduco [an important biscuit competitor] came out with its micro distributors on three-wheel motorbikes, we saw them immediately ... opportunities emerge continuously from TT channels, but it is extremely fragmented." (MDLZ, Interviewee 7). On the ground, sales teams use different methods to keep abreast of these fragmented changes. Communication technologies such as WhatsApp sales groups help enormously. This is supplemented by regular meeting points, which help coordinate various sources and pieces of market and competitor information. Similarly, developing the skills of sales people and small distributors at reading and picking up on market signals and tendencies on the ground becomes a key issue for local managers, as most of them have low levels of education; but this should not be a barrier to appointing them as point of sale operators or distributors: "The lack of employment and training means that the alternative of opening a point of sales in your home seems appealing. It's a sunk cost; part of the house is used and everything is done under the table [that is, taxes are not paid]. Also, they buy cheaper for their own consumption. This means that since there are so many small points of sale, the drop-size, the effectiveness of the visit and the effectiveness of the sale are very, very low. This makes it too complicated to obtain a profitable and effective distribution model." (MDLZ, Interviewee 7). In sum, given the significance dependence on TT, sensing and staying alert to market signals is key to developing effective RTM strategies. If unpicked and acted upon at the right time, market changes can disrupt channel structure or significantly undermine the performance of distributors at various levels of the distribution value chain.

Leveraging: Market fragmentation at grassroots levels also has important implications for how resources are stretched, flexed, and leveraged to find the optimum RTM tactics and strategies for reaching the end consumer. Very often, appointing a large-scale distributor is not necessarily an advantage to meeting the challenges of market fragmentation. For instance, one of the interviewees commented that: "... the big challenge in my opinion is that a distributor with a very big structure, where biscuits represent only 5 percent of its total invoicing, which at the same time is trying to foster the dedication, attention, and focus of the sales force and business, isn't a simple matter... [for instance] DG manages Mondelez Biscuits, all the Philip Morris portfolio, Diageo, Miller Beer, wines from various wineries, and more. It is in this context that biscuits disappear in this big portfolio, and when they arrive at the traditional trade channel with the point of sale's low purchase power, the biscuits get very low levels of coverage (MDLZ, Interviewee 7). As such, local managers are urged to be creative and explore alternative points of sale and store formats to 
extend their access and reach: “... For this reason, we started working with smaller sub-distributors and in some specific zones we are already with "micro distributors" [e.g. the Oreo three-wheeled motorcycles]. We also have two types of sub-distributor: small sub-distributors, who had already been supplying in the area with other products, and micro-distributors exclusively for the biscuits we are testing in particular areas. "(MDLZ, Interviewee 7). In such scenarios, the local managers seem to be the main initiators of ideas and the main decision makers on whom RTM strategies will work most effectively. Another interviewee explains the bottom-up exchange of information and interaction between levels of management before a particular RTM solution is implemented: "Paraguay is so different that it's impossible to apply a predetermined "recipe", so the locals who understand the context and the "oven temperature" [continuing with the metaphor of the recipe] are the ones who have to adjust the way of cooking. One change in distribution strategy, such as gradually moving toward many small distributors and away from a few large distributors, is defined locally between the Sales Managers and the General Manager. It's presented to the Head of the Cluster within the Annual Budget as part of the annual sales plan, and it's implemented. Logically, it gets communicated before advancing, but it's not something that gets defined at the outset and trickles down. It happens as a way of dealing with the issues we face. In distribution it's the other way around: we, "the locals", define the strategy and present it outside".

Appropriability: We also observe from the data that both MDLZ and NESN struggle to grow via TT because of inherent inadequacies and inflexibilities that exist in their distributors' distribution models. For instance, the standard distribution model of a typical large and established distributor would normally have the following issues when working with TT: (a) an exclusive sales force, sales room, supervisor, manager, presale model, and 24-hour delivery fit for MT model; and (b) a sales force that would avoid travelling long distances on roads not suitable for their vehicles, particularly in far-reaching rural areas; and (c) finding upon arrival at the point of sale that the purchase power is less than expected and might not be profitable. In contrast, appointing a smaller distributor with a smaller store format and lower operating costs can overcome these issues. The key, however is to produce the right sized product, packaging and price point 'fit' in order to access the purchasing power of the market. As one interviewee commented: "In order to continue the growth in supermarkets ...we started participating in as many chain promotions as possible, renting additional exhibition space, and many other 'push' initiatives that, when compared to the 'more genuine' growth in the traditional trade channels, were much less profitable. The Oreo presentations have four units, which we import solely to commercialize in the traditional trade channel. Although they are cheaper in 'out-of-pocket' costs because they are 30 grams, versus the 111-gram and 333-gram presentations that we sell in supermarkets, they are much more profitable ... and, like this example, there are many more reasons why I would say that the traditional channel is a more noble, interesting, and profitable partner. The key is to find how to get to them correctly." (MDLZ, Interviewee 1). Both MNEs, between 2014 and 2015, prior to attempting to pursue growth in the TT channel, adapted the product portfolio of their iconic brands (Oreo and Negresco) in order to address low "out of pocket" markets and maximise value capture for the biscuit's category, with low weight presentations of 34-50 grams (at $£ 0.20$ per package - retail selling price).

\section{Discussion}

\section{An empirical extension of resource-based RTM agility model}

Based on both sets of data, we empirically enriched and extended our original theoretical framework (Figure 1) with further constructs that provide more detail on the agility antecedents and adaptation influences underpinning how CPG MNEs' develop agile RTM strategies in Paraguay. Figure 3, below, presents an extension of our theoretical framework, informed by the empirical insights above. It argues that a CPG MNE's RTM strategy in an emerging context such 
as Paraguay is the outcome of multiple adaptation considerations from the ground up, which often demand simultaneous attention in tailoring effective and agile RTM strategies.

Figure 3: An empirically-extended resource-based RTM agility model for adapting international distribution in Paraguay

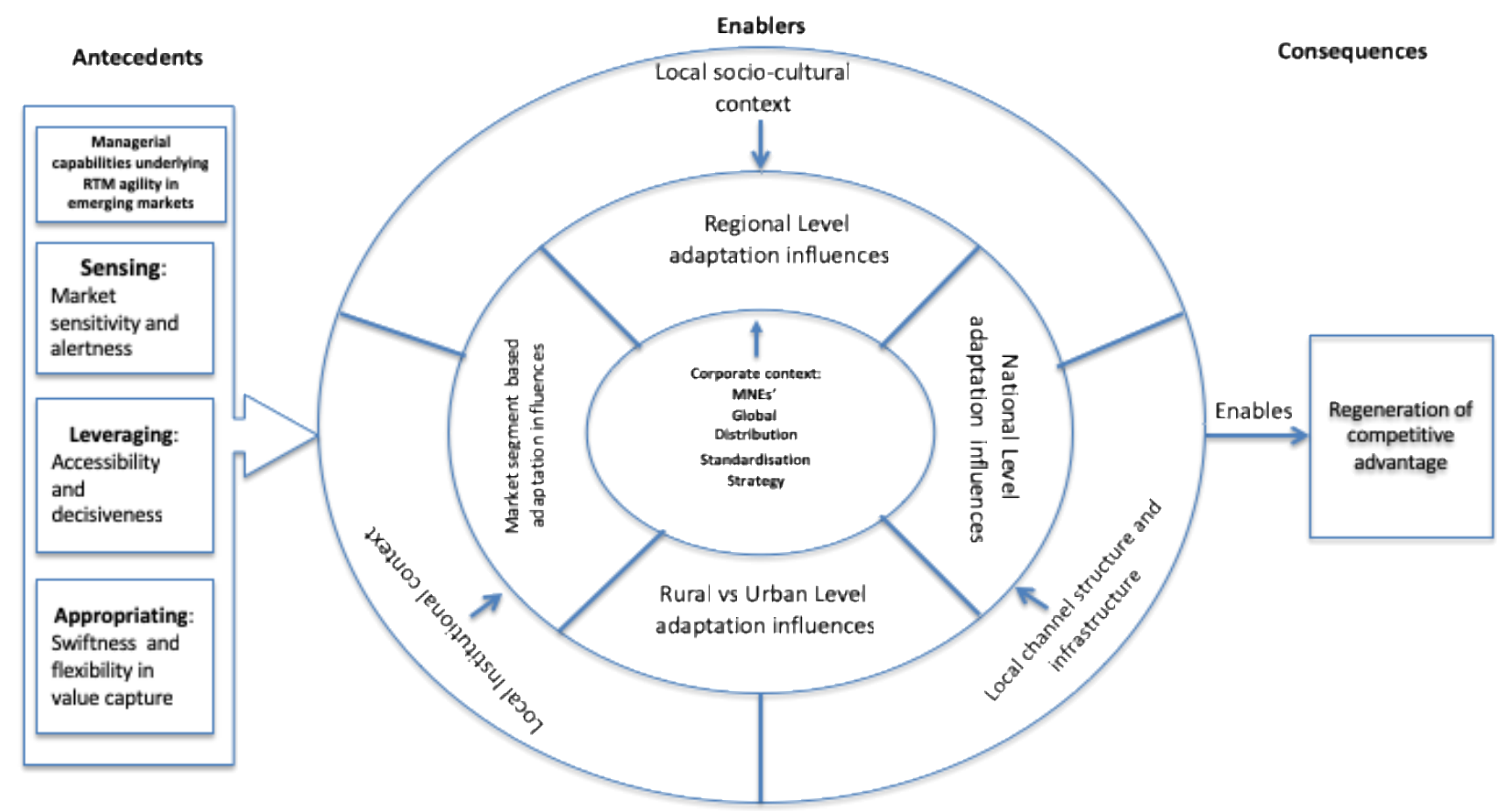

Based on the empirical evidence, between push and pull pressures, we characterize four distinct adaptation influences, namely regional, market segment-based, institutional, and distribution infrastructure-based adaptation influences. These influences further characterize the "theoretical space' to inform the kinds of decisions a CPG MNE has to make in ongoing and iterative thinking and dialogue about the shape, content, and direction of RTM strategies (Cespedes, 1988; Craig et al. 2011; Sinha \& Sheth, 2017; Rao-Nicholson \& Khan, 2017). This provides more direction to Corporate HQ on how the adaptation of the MNE's global distribution strategy should work. Unravelling these influences further enables Corporate HQ to make informed decisions on how to align strategic goals closer to the realities of local customers' needs, and the optimal distribution routes needed to reach them (Liu et al. 2016; Mbaye \& Seck, 2018). Our empirical evidence suggests that the agile RTM managerial capabilities become determinant at this point, and we observe that they are enacted in the Paraguayan distribution context in the following manner.

We defined sensing as alluding to heightened market sensitivity, alertness, and response to market dynamics in emerging countries. Our evidence illustrates that CPG MNEs can sense opportunities in emerging markets through developing local presence and maintaining strong network relationships with their ground-level distribution partners. For instance, the fact that the majority of the local populations in Paraguay live on just $£ 2$ per day or even less (D’Andrea et al. 2010; CCR, 2017) demands grassroots-level retail innovations in much smaller and less sophisticated formats (such as micro-distributors) to reach these consumers, and further territorial embeddedness (Hutchinson et al, 2009; Coe \& lee, 2013; Liu et al. 2016). These micro-store formats are, in turn, supported by collaborating with local distribution partners in setting up local warehousing and 
logistical facilities to quickly pick up and respond to possible opportunities in the market. Such new RTM initiatives can be controlled via "tailor-made metrics", focusing on growth, speed and reach in keeping aligned with local or territorial market characteristics and competition. Hence, we may infer that, in such markets, CPG MNEs might succeed in executing their RTM routes and initiatives by investing in their abilities to sense emerging markets from the ground up. They can do so by giving more autonomy to local distribution managers, and by effectively controlling the interface between these managers and HQ. Local managers are local champions (Fourné, 2012; Rao-Nicholson \& Khan 2017), and they can ensure RTM strategies are technically, economically, and culturally viable before implementation.

We took leveraging as alluding to accessibility and decisiveness around resource allocation and exploiting of complementarities within. Our empirical evidence illustrates that CPG MNEs can leverage best practices and resources from across the region or other similar markets to encourage standardized global distribution complementarities (D'Andrea et al. 2010; Zhang et al., 2010; Sinha \& Sheth, 2017; Rao-Nicholson \& Khan, 2017). However, there might be a need to create different kinds of micro-level formats of "points of sale" in respective markets; and in doing this, CPG MNEs might also face many difficulties like frequent, costly modifications in the distribution mix, dealing with multiple retail agents, and processing and delivering the products to their respective stores. However, by overcoming these obstacles, CPG MNEs can regenerate competitive advantage through their ability to stretch and flex their resources based on their regional standardized distribution model, and benefit from cost-efficient complementarities (Agatz et al., 2008). This observation is supported by the work of Ataman et al. (2010), who aver that different channels of distribution can have dissimilar impacts in different markets, highlighting the importance of taking individual and appropriate sales formats to customer segments at the right price. Further, Venugopal (2012) reinforces the need for companies to develop special strategies to reach rural retailers in developing countries, but to keep a close eye on associated costs. He explains that, since the cost of distribution is high, the viability of distribution to rural areas will only be profitable if companies plan effective promotional and sales strategies in parallel, to create awareness and increase demand (Venugopal, 2012). Similarly, Celly (1996) discusses the importance regional distribution channels and the distributors' experience in dealing in the market have with regard to business results, as well as the impact of distributors' relationship with those responsible on the company's marketing program. Celly also suggests that the confidence the company places in the distributor allows for enhanced coordination, which in turn reflects on fulfilment of business goals.

We defined appropriability as alluding to speed of thinking and action, imbued by flexibility in value capture. In empirically observing the CPG MNEs we note that their RTM agility does not indicate any direct correlation to financial performance; rather, the impact is on operational performance of RTM strategies and how they effectively help them to reach their consumers. This is also related to improvements in their operational and competitive abilities, as well as speed and flexibility when responding to sensed changes in the markets on the ground (Theodosiou and Leonidou, 2003; Ojha (2008; Coe \& Lee, 2013; Liu et al. 2016). We further infer that, in order to be effective, it is imperative for CPG MNEs to rapidly align their individual products with the most effective store formats locally, and with consumers' disposal incomes. In addition, their local managers also need to identify the optimal quantity to allocate to each distribution store format, in order to maximize value capture at every stage of the distribution value chain (Kumar et al. 2014). 


\section{Implications for international distribution and agility research and practice}

\section{Theoretical contributions and implications for research}

Emerging markets remain attractive, but their retailing environments are still new and developing, which poses enormous risks and challenges to MNEs' distribution agility at reaching their end consumers (Nandonde \& Kuada, 2016; Aguilera et al, 2017; Surdu et al. 2018). In these contexts, successfully reaching the end consumer depends on how much agility is exercised and the roles of dynamic managerial capabilities when micro-level RTM strategies are designed and executed. In this respect, our study contributes to research in three important ways:

Firstly, by juxtaposing the literature streams on dynamic capabilities, strategic agility and microfoundational perspectives, our study provides a nuanced understanding of RTM agility capabilities by suggesting it to be a multi-dimensional managerial capability, albeit from an international distribution perspective. Our research question stretches the notion of building and maintaining strategic agility, joining the call of agility researchers (Morton et al. 2018) emphasising the need for international managers to not only think of strategic agility as a one off or linear realisation but a gradual and responsive adaptive process that needs to be weaved into the strategy and workings of the organisation irrespective of its socio-economic context. This paper has tried to draw attention to this by looking at how RMT strategies are determined and developed at granular levels in one specific context, but wider research and understanding is needed to understand the organisational and market level intricacies of strategic agility and how it is put into practice. In examining how RTM agility capabilities exhibit themselves, we note that putting these capabilities to practice evolves overtime through multifaceted adaptation influences as MNEs foray into unknown territories, overlapping not only geographical but also managerial boundaries, and relying upon experiential learning by progressing in small steps while coping with uncertainty (Elg et al: 2017; Vendrell-Herrero et al. 2017). Practically, based on our observations of the findings, we also argue that the three RTM agility capabilities outlined in this paper are a conceptual extension of existing strategic agility research. They each have a significance of their own, but they are also need to be jointly considered in order for MNEs to succeed in the markets, like Paraguay, and enable them to continuously regenerate competitive advantage. We acknowledge that our study is too limited in its empirical scope to make substantive conclusions or theoretical generalizations, although we hope that the insights generated will aid further empirical investigation and validate findings from other similar emerging economies, or through the empirical lens of Mondelez International, Nestlé, and other MNEs in other socio-economic contexts.

Secondly, our findings highlight the roles played by the regional distribution strategies of MNEseither standardization or adaptation strategies - in designing and implementing international marketing strategies, showing how agile RTM strategies are enacted and adapted at micro-market levels. In this respect, our evidence reveals that optimal RTM strategies are an agile expression of an interface between the dynamic strategic agility capabilities of RTM managers and the many granular, rich and complex adaptation considerations influencing the implementation of MNEs' global distribution strategy (Ghoshal, 1987; Yip, 1989; Rugman and Verbeke, 2001; Rugman et al. 2012; Rao-Nicholson \& Khan, 2017). Our findings contribute to research on managing global 
strategy and regional strategy, and on reconciling global autonomy and local, grassroots-level coordination with strategic agility in sensing, leveraging and appropriating value capture across MNEs' global distribution networks in unorganised socio-economic contexts (Kumar et al. 2014). Our findings unravel some of the grassroots level intricacies and influences involved, and some possible approaches, but much scholarly attention is still needed in order to understand the wider implications of successfully executing global strategy. Thirdly, our study contributes to strategic agility research in the emerging economy context by highlighting the role played by local context at granular levels and the importance of agility capabilities in carrying out RTM strategies in emerging economies. Strategic agility research in the emerging economies context is still nascent, and our paper joins a number of scholarly debates emphasising the role and influence of emerging economies' local contexts, and their impact on the international strategy of MNEs (Sheth, 2011; Gomes et al, 2011; Fourné 2012; Gomes et al. 2012; Fourné et al. 2014; Kumar et al. 2014; Nandonde \& Kuada, 2016; Mbaye \& Seck, 2018).

\section{Implication for managers}

Managerial implications can also be drawn from the framework and findings of this research. The conceptual framework, for instance, depicts the critical RTM agile capabilities that need to be acquired at micro-market levels to enable effective RTM strategies in responding to multifaceted adaptation influences. In line with Fourné (2012) and Fourné et al (2014) we suggest that distribution managers in emerging markets have to be more alert and aware to these influences in developing and adapting their RTM strategies. The agile managerial attributes that we highlight provide a basis for coping with these influences with agility at micro-market levels. In turn, this also means that management at corporate levels in MNEs needs to provide more autonomy for regional or country-level distribution managers, both expatriate and local, to be able to drive and flex ideas and resources with strategic agility on the ground can better can better guide groundlevel sales agents and distribution partners through the intricacies of emerging markets by sensing and seizing local opportunities, leveraging appropriate resources, and organizing for value capture. This process can to be overseen by HQ, but the autonomy and agile qualities of distribution managers is a prerequisite to successfully navigating the volatility and uncertainty which seem to be the norm in these markets (Samiee, 1993; Sheth, 2011; Ruschton, 2014).

The above point further helps us to also assert that when deciding about international adaptation strategies, MNE managers need to more open-minded and go beyond the examination of centralised global or regional distribution strategies to consider the micro level RTM agility capabilities of their distribution and RTM managers. For the latter, the question boils down to a search for skills and talent through intake of capable management and suitable dynamic capabilities to sense, leverage and appropriate market changes and opportunities at granular levels. By empirically illustrating the organizational dilemmas, practices, and managerial activities underlying RTM agility capabilities, we inform distribution managers on how to succeed in emerging markets like Paraguay at micro level. For instance, to succeed, the sensing of new opportunities needs to be aligned with how resources are leveraged to fit RTM realities in given markets, i.e., in implementing optimal sales packaging and store formats at the right price. Hence, recognizing opportunities and realizing full value potential requires the development, transference, and sometimes simplification of distribution channels with agility at grassroots levels, in order to find the optimal ways to reach the end consumer. 
The study has some limitations. We caution on the results of this study due to its exploratory and qualitative nature. More holistic research examining the RTM agility capabilities and micro market-level adaptation influences on the global strategies of MNEs is called for. In particular, and particularly from a practice perspective, what do agile distribution do to enable effective distribution strategies in diverse socio-economic contexts would seem to deserve more empirical attention. Furthermore, the results need to be validated through more robust quantitative research and replicated in other CPG product-market ventures, industries and economies to explore their generalizability in other country contexts than Paraguay. It would also be interesting to extend the study from MNES companies to local leading companies and contrast their distribution strategies.

In sum, this research combines RBV, strategic agility and micro foundation perspectives in an attempt to understand how CPG MNEs' RTM agility capabilities is exercised at RTM levels in response to multi-faceted adaptation influences in the context of Paraguay. Given the accelerating retail growth potential of Paraguay and other similar emerging markets, an understanding of RTM agility capabilities is required at granular levels to understand how to effectively adapt MNEs' global distribution strategies. Our RTM agility frameworks provide micro-level insights for researchers and managers interested in how the global distribution value chain of MNEs works, how it is adapted to meet the realities of emerging markets like Paraguay. Distribution managers in markets like these need to understand the RTM issues at play, and how they can exercise agility in the adaptation processes when seeking new ways to sense dynamic market changes, leverage assets and capabilities, and appropriate value capture in their distribution value chain. International management researchers and practitioners, and particularly those interested in the effective management of global distribution strategies, have much to learn, study, and investigate in this dynamism, as we seek to further our understanding of strategic agility capabilities in diverse socioeconomic contexts.

\section{Appendix 1: Table 1: Profile of Interviewees}

\begin{tabular}{|l|l|l|l|}
\hline Interviewees & Company & Category / Company Description & Position \\
\hline $\mathbf{1}$ & Mondelez & Biscuits (Multinational) & $\begin{array}{l}\text { General Manager Uruguay \& } \\
\text { Paraguay Cluster }\end{array}$ \\
\hline $\mathbf{2}$ & Mondelez & Biscuits (Multinational) & Commercial Manager Paraguay \\
\hline $\mathbf{3}$ & Mondelez & Biscuits (Multinational) & Sales Manager Paraguay \\
\hline $\mathbf{4}$ & Nestlé & Biscuits (Multinational) & $\begin{array}{l}\text { Sales Manager Paraguay (former } \\
\text { employee) }\end{array}$ \\
\hline $\mathbf{5}$ & Nestlé & Biscuits (Multinational) & $\begin{array}{l}\text { Category Manager Paraguay } \\
\text { (former employee) }\end{array}$ \\
\hline
\end{tabular}




\begin{tabular}{|c|c|c|c|}
\hline 6 & Nestlé & Biscuits (Multinational) & Distributor (Owner and Manager) \\
\hline 7 & Mondelez & Biscuits (Multinational) & $\begin{array}{l}\text { Distributors Visibility \& Training } \\
\text { Manager - Paraguay }\end{array}$ \\
\hline 8 & Mondelez & Biscuits (Multinational) & $\begin{array}{l}\text { Former Commercial Manager - } \\
\text { Paraguay }\end{array}$ \\
\hline 9 & Mondelez & Biscuits (Multinational) & $\begin{array}{l}\text { Former General Manager - } \\
\text { Uruguay \& Paraguay Cluster }\end{array}$ \\
\hline 10 & Bimbo & $\begin{array}{l}\text { Biscuits (Multinational) It is the } \\
\text { world's largest baking company } \\
\text { and has some of the widest }\end{array}$ & $\begin{array}{l}\text { Former Commercial Manager - } \\
\text { Paraguay }\end{array}$ \\
\hline 11 & Bimbo & $\begin{array}{l}\text { distribution networks in Paraguay } \\
\text { and the United States. }\end{array}$ & $\begin{array}{l}\text { Former Sales Operations Manager } \\
\text { - Paraguay }\end{array}$ \\
\hline 12 & $\begin{array}{l}\text { Mazzei \& } \\
\text { Gullón }\end{array}$ & $\begin{array}{l}\text { Biscuits (local company) \& Gullón } \\
\text { (Multinational) Master Distributor }\end{array}$ & Current Commercial Manager \\
\hline 13 & Marilan & $\begin{array}{l}\text { Biscuits (Brazilian Regional } \\
\text { company) }\end{array}$ & $\begin{array}{l}\text { Master Distributor - Former } \\
\text { General Manager }\end{array}$ \\
\hline 14 & Marilan & $\begin{array}{l}\text { Biscuits (Brazilian Regional } \\
\text { company) }\end{array}$ & $\begin{array}{l}\text { Master Distributor - Director \& } \\
\text { Owner }\end{array}$ \\
\hline 15 & Marilan & $\begin{array}{l}\text { Biscuits (Brazilian Regional } \\
\text { company) }\end{array}$ & $\begin{array}{l}\text { Master Distributor - Current } \\
\text { General Manager }\end{array}$ \\
\hline 16 & Marilan & $\begin{array}{l}\text { Biscuits (Brazilian Regional } \\
\text { company) }\end{array}$ & $\begin{array}{l}\text { Master Distributor - Former } \\
\text { Marketing Manager }\end{array}$ \\
\hline 17 & Marilan & $\begin{array}{l}\text { Biscuits (Brazilian Regional } \\
\text { company) }\end{array}$ & Commercial Manager - Paraguay \\
\hline 18 & Marilan & $\begin{array}{l}\text { Biscuits (Brazilian Regional } \\
\text { company) }\end{array}$ & Sales Manager Interior \\
\hline 19 & Marilan & $\begin{array}{l}\text { Biscuits (Brazilian Regional } \\
\text { company) }\end{array}$ & Sales Manager Asunción \\
\hline 20 & Arcor & Biscuits (Multinational) & Former Sales Manager - Paraguay \\
\hline
\end{tabular}




\section{Appendix 2:}

\begin{tabular}{|c|c|}
\hline \multicolumn{2}{|r|}{ Table 2: Theoretical constructs and supporting evidences } \\
\hline $\begin{array}{l}\text { Theoretical } \\
\text { constructs }\end{array}$ & Some illustrative excerpts from Data \\
\hline \multicolumn{2}{|r|}{ Antecedents: Agile Managerial Capabilities } \\
\hline $\begin{array}{l}\text { Sensing: } \\
\text { Market } \\
\text { sensitivity and } \\
\text { alertness }\end{array}$ & $\begin{array}{l}\text { "It's such a small market that any change in our competitors or the clients is old news within } 15 \\
\text { days or less ... When Bauduco [an important biscuit competitor] came out with its micro } \\
\text { distributors on three-wheel motorbikes, we saw them immediately ... nowadays with WhatsApp I'm } \\
\text { connected with my whole team minute by minute. We have different WhatsApp groups where every } \\
\text { member of sales can discuss best practices, any bit of news from offers, launches, product lots with } \\
\text { expiration limits ... everything. These days technology helps a lot in ways like this. Furthermore, we } \\
\text { have our monthly sales meetings with the whole DG team, where we go over volumes and CCR } \\
\text { [referring to a local market audit similar to Nielsen's] ... Opportunities emerge continuously from } \\
\text { the TT channels, but it is extremely fragmented." (MDLZ, Interviewee 7) } \\
\text { The lack of employment and training makes it that the alternative to opening a point of sales in your } \\
\text { home seems appealing. It's a sunk cost; part of the house is used and everything is done under the } \\
\text { table [that is, taxes are not paid]; Also, they buy cheaper for their own consumption. This means } \\
\text { that since there are so many small points of sale, the drop-size, the effectiveness of the visit and the } \\
\text { effectiveness of the sale are very, very low. This makes it too complicated to obtain a profitable and } \\
\text { effective distribution model." (MDLZ, Interviewee 7) }\end{array}$ \\
\hline
\end{tabular}




\begin{tabular}{|c|c|}
\hline & $\begin{array}{l}\text { "When it comes to distribution, having market sensitivity and having the "alarms" go off, if } \\
\text { something goes wrong, is luckily a lot simpler than in other areas. Just going out to the streets } \\
\text { often and seeing the distribution and sales reports is enough. Example: the Mini-market concept } \\
\text { didn't exist } 2 \text { years ago, these City Markets that already have } 70 \text { subsidiaries and Biggie } 20 \text { (he } \\
\text { refers to businesses that are like Tesco Express in the UK), simply seeing the opening of these } \\
\text { mini-markets already sets off an alarm that you have to decide on some things within your } \\
\text { distribution strategy" (Interviewee 20) }\end{array}$ \\
\hline $\begin{array}{l}\text { Leveraging: } \\
\text { Accessibility } \\
\text { and } \\
\text { decisiveness }\end{array}$ & 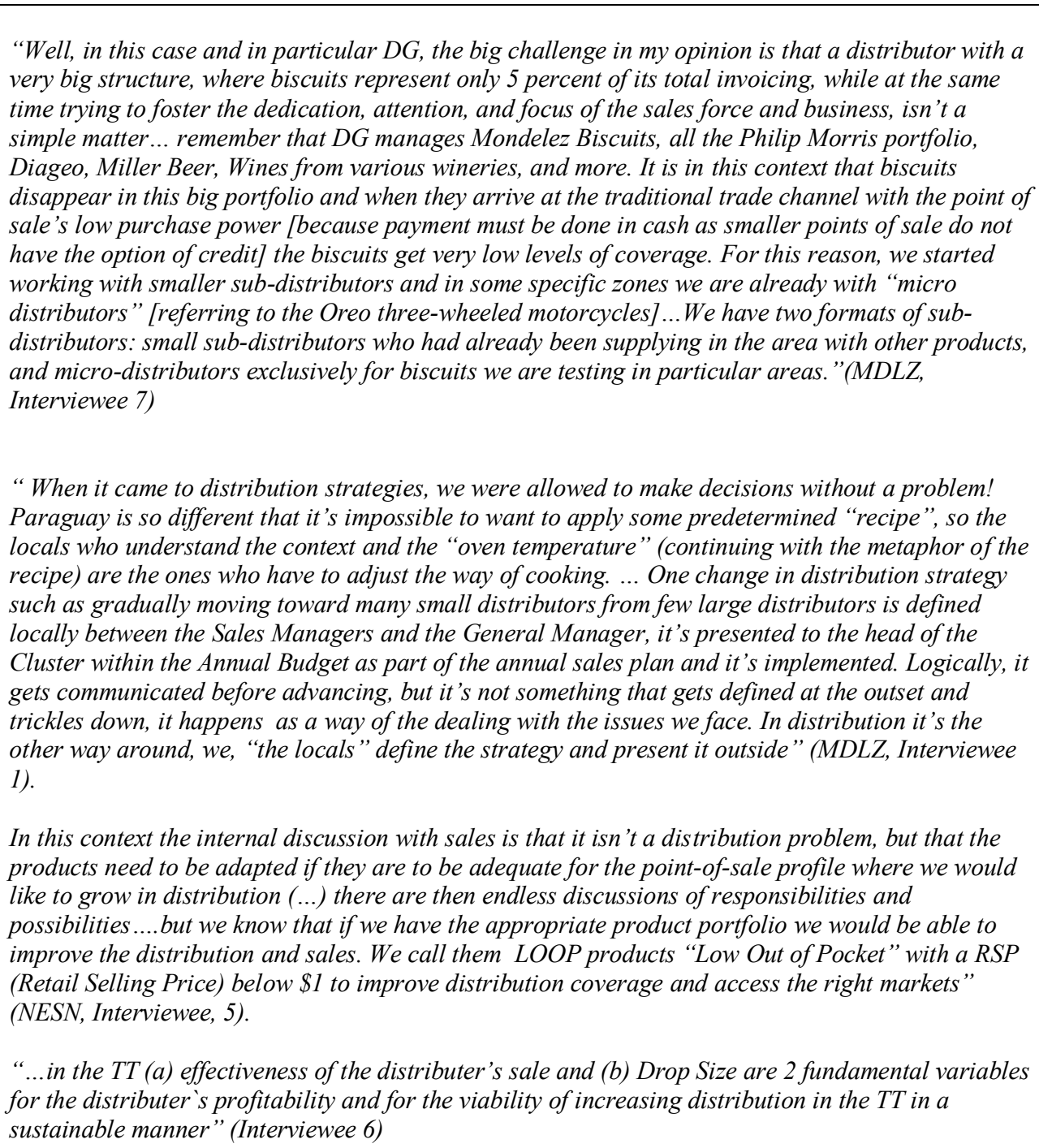 \\
\hline $\begin{array}{l}\text { Appropriability: } \\
\text { Swiftness and } \\
\text { flexibility in } \\
\text { value capture }\end{array}$ & $\begin{array}{l}\text { "In order to continue the growth in supermarkets - something that was not simple because we } \\
\text { already had high performance levels - we started participating in as many chain promotions as } \\
\text { possible, renting additional exhibition space, and many other 'Push' initiatives that (a) when } \\
\text { compared to the 'more genuine' growth in the traditional trade channels, were much less } \\
\text { profitable.,(b) these Oreo presentations that have four units, which we import solely to } \\
\text { commercialize in the traditional trade channel, although they are lower in 'out-of-pocket' costs } \\
\text { because they are } 30 \text { grams, versus the } 111 \text {-gram and 333-gram presentations that we sell in } \\
\text { supermarkets, they are much more profitable ... and, like this example, there are many more reasons } \\
\text { why I would say that the traditional channel is a more noble, interesting, and profitable partner. The } \\
\text { key is to find the way of how to get to them correctly." (MDLZ, Interviewee 1) }\end{array}$ \\
\hline
\end{tabular}




\begin{tabular}{|c|c|}
\hline & $\begin{array}{l}\text { "Well, at the level of implementation I think that the changes in distribution strategy are also } \\
\text { simpler. If we're talking concretely it is about adapting or changing the distributors as per the } \\
\text { market needs. If there are signed contracts, in place, that establishes the pre-notice window and the } \\
\text { company exercises its right to make modifications, the distributor is simply informed. They're } \\
\text { presented with the new zone, and the zone's Sales Supervisor of Arcor who spends the first few } \\
\text { months working in the modified zone to make the transition and train the distributor. If there } \\
\text { weren't a signed contract, then from a legal standpoint there could be some contingencies and then } \\
\text { the implementation isn't so simple. The good thing is that since the new strategy (smaller } \\
\text { distributors) has been yielding good results, now that the invoicing levels can be proven to be } \\
\text { recovered, there's a bit less resistance from the side of the distributors to change, even if they are } \\
\text { not legally obliged; because obviously nobody likes it when their zone is reduced" (Interviewee 20) } \\
\text { Some adjustments to the portfolio have been made with low weight presentations (SKUs) in brands } \\
\text { such as Negreso and Nesfit (Nestlé biscuits brands). And I understand that from the sales area, } \\
\text { constant incentives were given to the sales force and special actions were taken for the channel, in } \\
\text { order to make it more competitive (NESN, Interviewee 5) } \\
\text { "With respect to the "Way of Selling”, our sales force mainly get around on motorbike, in all cases } \\
\text { they make a presale and deliver it between } 24 \text { and } 48 \text { hours depending on the area. There are clients } \\
\text { who have a weekly visit, others a biweekly one and there are more peripheral areas where the visit } \\
\text { is monthly... On one hand we have launched small packaged products in the last years and one the } \\
\text { other hand shrunk the areas to have increasingly smaller distributers." (NESN, Distributor, } \\
\text { Interviewee 6). }\end{array}$ \\
\hline \multicolumn{2}{|r|}{ Enablers: Local contextual influences } \\
\hline $\begin{array}{l}\text { Regional Level } \\
\text { adaptation } \\
\text { influences }\end{array}$ & 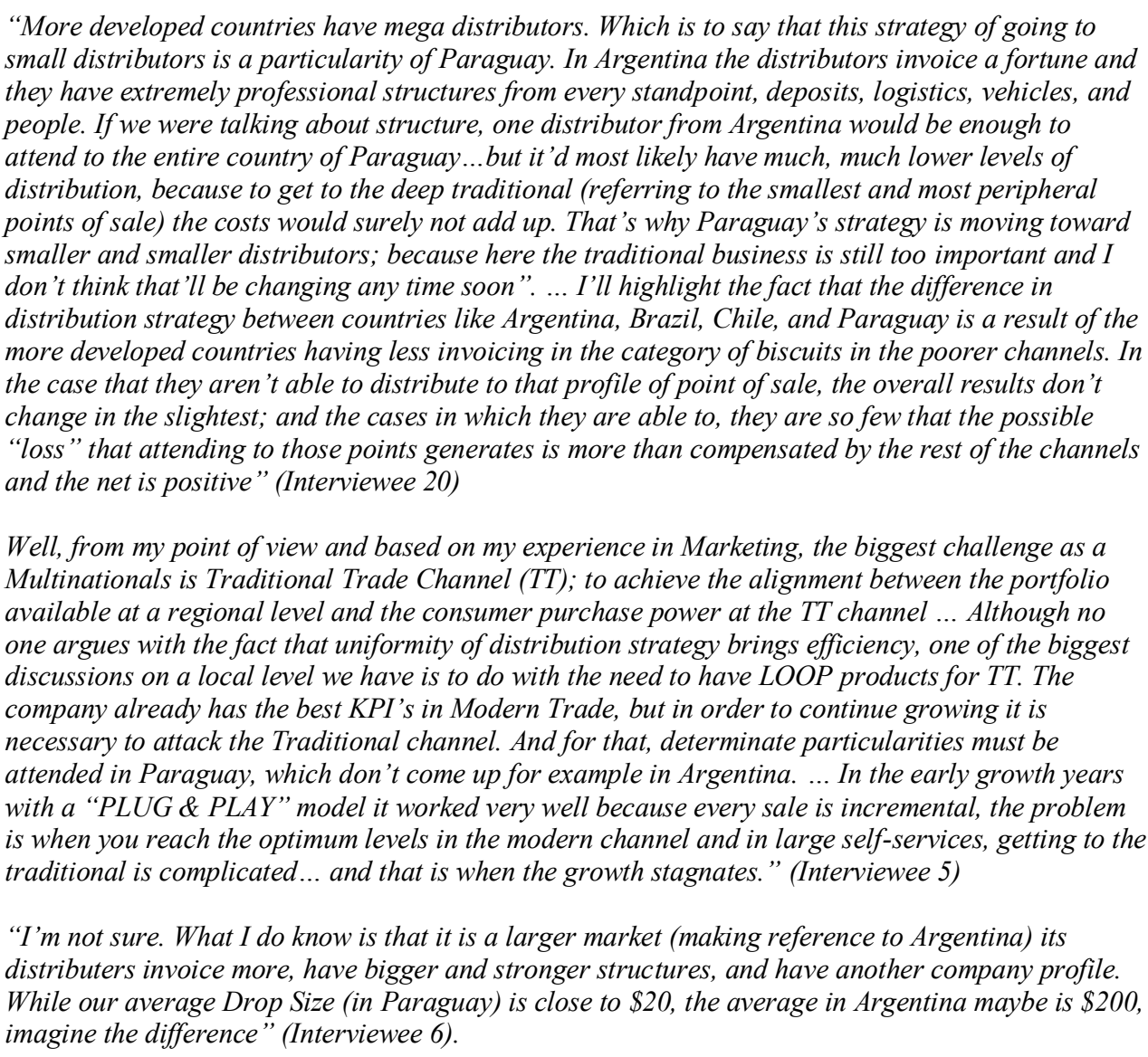 \\
\hline National Level & $\begin{array}{l}\text { "Nationally, the impact of zone size and the distances in which distribution services must be } \\
\text { provided is directly related to the costs of the distributor. The larger the zone, the longer the }\end{array}$ \\
\hline
\end{tabular}




\begin{tabular}{|c|c|}
\hline $\begin{array}{l}\text { adaptation } \\
\text { influences }\end{array}$ & $\begin{array}{l}\text { distance, the higher the cost, and there's less focus on attending to the smaller, unprofitable } \\
\text { points of sale. Arcor's strategy and how well they're doing, is a clear example: Not only does } \\
\text { decreasing the distribution size lower costs, but it also forces them to find the way to attend to } \\
\text { the smaller clients so that their business survives. They come to depend on that, and they reinvent } \\
\text { themselves" (Interviewee, 20) } \\
\text { "Nestlé Paraguay's strategy in route-to-market terms consists of direct distribution to supermarkets } \\
\text { and main wholesalers (the most important located in "Abasto Market"), as well as distributors for } \\
\text { the rest of the traditional trade channels. When we speak of supermarkets we refer to the most } \\
\text { relevant key accounts: Retail, Real, Salema, España... (etc). In the case of wholesalers, we also } \\
\text { refer specifically to the most relevant, the rest is via distributors.., and The fact that the current } \\
\text { distributors don't achieve good coverage levels with the current portfolio in the local context is very } \\
\text { relevant to us because TT represent more than 70\% of the biscuits market. Achieving high levels of } \\
\text { distribution, with good rotation at the points of sales would impact very positively on Nestle's } \\
\text { results in Paraguay" (Interviewee 5) }\end{array}$ \\
\hline $\begin{array}{l}\text { Rural vs Urban } \\
\text { Level } \\
\text { adaptation } \\
\text { influences }\end{array}$ & $\begin{array}{l}\text { "Arcor Paraguay has direct distribution to Supermarkets and uses distributors for the rest of the } \\
\text { channels. And that amount of distributors grows with each passing year. The strategy goes down } \\
\text { that path (...)If it has one distributor in a zone that includes for example San Lorenzo, Luque, and } \\
\text { Lambaré (3 "neighborhoods" of Gran Asunción), as a first step it's divided in } 2 \text { and then it ends up } \\
\text { being } 3 \text { where before it was just 1" (Interview 20) } \\
\text { "I have over } 30 \text { years related to biscuit sales in the interior of Paraguay. } \\
\text { An increasingly marked tendency (...) is to have more and more distributors with lighter } \\
\text { structures and smaller areas; to optimize operating costs and to be able to "squeeze more juice" } \\
\text { out of the area... In the Traditional Trade channel, which in fact in my region (the interior of } \\
\text { Paraguay) is the great majority, the low effectiveness of the visit (\% of points of sale visited that } \\
\text { purchase from you) and the low Drop Size (average sales of the route) make it very complicated } \\
\text { to achieve high levels of coverage (as the company intends) in a profitable manner. The issue is } \\
\text { that we have to reach all the forms of points of sales, the good and the bad; but to have routes } \\
\text { which systematically lose money is not easy. } \\
\text { (...) Out of the 6,000 stores that there are in my area, we are able to visit only 1,500 to 2,000 } \\
\text { during the month (only the biggest and those with the greatest sales). If a visit to the other } 4000 \\
\text { unattended points is attempted, it will imply the need for more sales reps, more vehicles and } \\
\text { travelling further distances, and the income will not cover the costs" (Interviewee 6).... }\end{array}$ \\
\hline $\begin{array}{l}\text { Market } \\
\text { segment-based } \\
\text { adaptation } \\
\text { influences }\end{array}$ & $\begin{array}{l}\text { "This strategy of going to smaller distributors has been giving Arcor some excellent results as they } \\
\text { are strictly market-based, it's incredible how, if the original distributor would invoice 1000, they } \\
\text { split it in } 3 \text { sub-distributors for different clientele, and in little time each one would be invoicing } \\
1000 \text { once more, tripling the invoicing for the original zone. And it all happens because of a } \\
\text { profitability factor...the big distributor with more structure and costs concentrates on the bigger } \\
\text { clients, which are more profitable. Dividing the zone and leaving them smaller, the new smaller } \\
\text { distributor has no choice but to lower costs and provide service to smaller clients" (Interviewee 20). } \\
\text { "Precisely the key lies in the purchasing power of the market at each point of sale... and the } \\
\text { rotation of the portfolio in each point of sale, which affects the drop size and the effectiveness of the } \\
\text { visit. Regardless of the number of points of sales that the market has, that the drop size is lower } \\
\text { precisely talks about what each point of sale purchases. So the challenge which is presented is how } \\
\text { to cover the cost of a visit of one point of sale with the purchase of one point of sale... it is very } \\
\text { different" (Interviewee 6) }\end{array}$ \\
\hline
\end{tabular}




\section{References}

Accenture, 2014). Supply Chain Success Factors in Emerging Markets: Accenture Global Operations Megatrends Study, available at https://www.accenture.com/t20150523T024836_w_ /inen/ acnmedia/Accenture/ConversionAssets/DotCom/Documents/Global/PDF/Dualpub_2/Accenture-Operations-MegatrendsEmerging-Markets.pdf (accessed February 28th January 2018)

Adomako, S., Amankwah-Amoah, J., Dankwah, G.O., Danso, A., Donbesuur, F., 2019. Institutional voids, international learning effort and internationalization of emerging market new ventures. Journal of International Management 100666. https://doi.org/10.1016/j.intman.2019.04.001

Agatz, N., Fleischmann, M. \& van Nunen, J., 2008. E-Fulfillment and Multi-channel Distribution - A Review. European Journal of Operational Research, 187(2), 339-356. 
Anderson, E. \& Coughlan, A., T., 1987. International Market Entry and Expansion via Independent or Integrated Channels of Distribution. Journal of Marketing, 51, 71-82.

Ataman, M. B., Van Heerde, H.J. and Mela, C.F., 2010. The Long-term Effect of Marketing Strategy on Brand Sales. Journal of Marketing Research, 47(5), 866-882.

Akaah, I. P., 1991). Strategy standardization in international marketing: an empirical investigation of its degree of use and correlates. Journal of Global Marketing, 4, 39-62.

Aguilera, R.V., Ciravegna, L., Cuervo-Cazurra, A.and Gonzalez-Perez, M.G., 2017. Multilatinas and the Internationalization of Latin American Firms. Journal of World Business, $52(4), 447-60$.

Alexander, N. \& Doherty, A.M., 2010. International retail research: focus, methodology and conceptual development. International Journal of Retail \& Distribution Management. 38(11/12), 928-942.

Barney, J., 2001. Is the Resource-Based 'View' a Useful Perspective for Strategic Management Research? Yes. Academy of Management Review 26(1), 41-56.

Barney, J., Felin, T., 2013. What Are Microfoundations?. Acad. Manag. Perspect. 27(2), 138155.

Boojihawon, D. K.; Dimitratos, P. and Young, S., 2007. Characteristics and influences of multinational subsidiary entrepreneurial culture: the case of the advertising sector. International Business Review. 16 (5), 549-572.

Ben-shabat, H., Moriarty, M., Peterson, E. \& Kassack, J., 2018. Emerging Market Retailing in 2030: Future scenarios and the $\$ 5.5$ Trillion Swing, A.T. Kearney Global Consumer Institute, available

at: https://www.atkearney.co.uk/documents/10192/8355530/Emerging+Market+Retailing+in +2030.pdf/54cb66fc-8aee-445f-bf55-b3aed2e0227b (accessed 29th January 2018)

Bianchi, C., 2009. Retail Internationalisation from Emerging Markets: Case Study Evidence from Chile. International Marketing Review. 26(2), 221-43.

Bianchi, C., 2006. Home Depot in Chile: Case Study. Journal of Business Research, 59(3), 391-93.

Bianchi, C., \& Saleh, Md. A., 2011. Antecedents of Importer Relationship Performance in Latin America. Journal of Business Research. 64(3), 258-65. 
Boddewyn, J. J., Soehl, R., and Picard, J., 1986. Standardization in international marketing: is Ted Levitt in fact right? Business Horizons. 29, 69-75.

Bozkurt, Ö., 2014. Book Review. Journal of International Management 20, 275-277. https://doi.org/10.1016/j.intman.2013.10.006

Bucklin, R.E., Sivaramakrishnan, S., and Silva-Risso, J. M., 2008. Distribution Intensity and New Car Choice. Journal of Marketing Research,45(4), 473-486.

Candace A. M. \& Kalliny, M., 2012. Academic research in the Latin American context: a review of the empirical literature 1990-2010. Multinational Business Review 20:3, 231-247.

Cavusgil, T. S. \& Zou, S, 1994. Marketing strategy-performance relationship: an investigation of the empirical link in export market ventures. Journal of Marketing. 58,1-21.

Cespedes, F. V., 1988. Channel Management is General Management. California Management Review. 31(1), 98-118.

CCR Paraguay, 2017. Status de Consumo Paraguay - Total Canasta Consumo Masivo, April.

Celly, K. S. \& Frazier, G. L., 1996. Resultado del comportamiento basados en las relaciones de canal. Journal of Marketing Research. 33 (May).

Chen, E.L., Katila, R., McDonald, R., \& Eisenhardt, K.M., 2010. Life in the fast lane: origins of competitive interaction in new vs. established markets. Strategic Management Journal. 31(13), 1527-1547

Coe, N. M. \& Lee., Y. S., 2013. We've learnt how to be local': the deepening territorial embeddedness of Samsung-Tesco in South Korea. Journal of Economic Geography. 13(2) 327-356.

Collinson, S. \& Liu, Y., 2018. Recombination for Innovation: Performance Outcomes from International Partnerships in China, $R \& D$ Management, forthcoming, http://dx.doi. org/10.1111/radm.12293.

Craig, C. S. \& Douglas, S. P., 2011. Empowering Rural Consumers in Emerging Markets. International Journal of Emerging Markets. 6 (4), 382-393.

Cuervo-Cazurra. A., 2016. Multilatinas as sources of new research insights: The learning and escape drivers of international expansion. Journal of Business Research. 69(6), 1963-1972. 
D’Andrea, G., Silvestri, L., Costa, L., Fernandes, F., \& Foss, F., 2010. Spinning the Wheel of Retailing in Latin America. Innovation Platforms for Emerging Consumer. International Studies of Management \& Organisation. 40(2), 52-73.

Dawar, N. and Chattopadhyay, A., 2002. Rethinking Marketing Programs for Emerging Markets. Long Range Planning. 35(5), 457-474.

Debi P. M., 2008. FMCG Distribution Channels in India: Challenges and Opportunities for Manufacturers and Retailer. The Journal of Global Business Issues, 175-182.

Deloitte Paraguay, 2016. Doing Business in Paraguay. Haciendo negocios en Paraguay, Asunción, 1-59.

Del Giudice, M., Soto-Acosta, P., Carayannis, E., Scuotto, V., 2018. Emerging perspectives on business process management (BPM): IT-based processes and ambidextrous organizations, theory and practice. Business Process Management Journal; Bradford 24, 1070-1076. http://dx.doi.org.ezproxye.bham.ac.uk/10.1108/BPMJ-09-2018-336

Del Giudice, M., Arslan, A., Scuotto, V., Caputo, F., 2017. Influences of cognitive dimensions on the collaborative entry mode choice of small- and medium-sized enterprises. International Marketing Review; London 34, 652-673. http://dx.doi.org.ezproxye.bham.ac.uk/10.1108/IMR-05-2016-0098

Devinney, T., 2013. Is microfoundational thinking critical to management thought and practice? Acad. Manag. Perspect. 27(2), 81-84.

Diaz, A., Lacayo, J., and Salcedo, L., 2007. Cómo vender a las tiendas de barrio en América Latina" ("How to sell to Traditional Trade in Latin America. The McKinsey Quarterly, 81-93.

Douglas, S. P. and Wind, Y., 1987. The myth of globalization. Columbia Journal of World Business, 22, 19-29.

Doz, Y., \& Kosonen, M., 2008a. The dynamics of strategic agility: Nokia's rollercoaster experience. California Management Review, 50(3): 95-118.

Doz, Y. L., \& Kosonen, M., 2008b. Fast strategy: How strategic agility will help you stay ahead of the game. Pearson Education.

Doz, Yves L. and Kosonen, M., 2010). Embedding Strategic Agility. A Leadership Agenda for Accelerating Business Model Renewal. Long Range Planning. 43, 370-382. 
Dyer, L. \& Shafer, R. A., 1998. From human resource strategy to organizational e ectiveness: Lessons om research on organizational agility (CAHRS Working Paper \#98-12). Ithaca, NY: Cornell University, School of Industrial and Labor Relations, Center for Advanced Human Resource Studies. h@p://digitalcommons.ilr.cornell.edu/cahrswp/125

Eisenhardt, K.M. and Graebner, M.E. (2007), "Theory building from cases: opportunities and challenges", Academy of Management Journal, Vol. 50 No. 1, pp. 25-32.

Elg, U. Ghauri, P.N., Child, J., and Collinson, S., 2017. MNE Microfoundations and Routines for Building a Legitimate and Sustainable Position in Emerging Markets. Journal of Organizational Behaviour. 38(9), 1320-1337

Elinder, E., 1961. How International Can Advertising Be. International Advertiser, December, $12-16$.

Engelen, A., Schmidt, S., Buchsteiner, M., 2015. The Simultaneous Influence of National Culture and Market Turbulence on Entrepreneurial Orientation: A Nine-country Study. Journal of International Management 21, 18-30. https://doi.org/10.1016/j.intman.2014.12.002

Fayezi, S., Zutshi, A. and O'Loughlin, A. (2017). Understanding and development of supply chain agility and flexibility: A structured literature review. International Journal of Management Reviews, Vol 19, No 4, pp.379-407.

Fairfield, T. (2015) “Case Selection.” Cambridge University Press

Felin, T., Foss, N. J., \& Ployhart, R. E. (2015), "The microfoundations movement in strategy and organization theory", Academy of Management Annals, Vol 9, pp. 575-632.

Ferraris, A., Santoro, G., Scuotto, V., 2018. Dual relational embeddedness and knowledge transfer in European multinational corporations and subsidiaries. J of Knowledge Management JKM-09-2017-0407. https://doi.org/10.1108/JKM-09-2017-0407

Fleury, A., Fleury, M.T.L., Borini, F.M., 2013. The Brazilian Multinationals' Approaches to Innovation. Journal of International Management 19, 260-275. https://doi.org/10.1016/j.intman.2013.03.003

Förster, B., Keller, J., von der Gracht, Heiko A., and Darkow, Inga-Lena (2014), "Delphibased strategic issue management: crafting consumer goods supply chain strategy," 
International Journal of Physical Distribution \& Logistics Management, Vol. 44Issue 5, pp. 373-391.

Forteza, J.A. (1997), Competing in emerging countries: the case of Latin America, strategy+business, second quarter, April/Issue 7

Fourné, S. (2012), Strategic agility: an emerging markets perspective, in 2012 IEEE International Technology Management Conference, Dallas, TX USA, June 25-27, 2012, pp.98107

Fourné, S., Jansen, J., and Mom, T. (2014), "Strategic Agility in MNEs: Managing Tensions to Capture Opportunities across Emerging and Established Markets," California Management Review, Vol. 56 No. 3.

Frazier, G.L. (1999), "Organizing and Managing Channels of Distribution," Journal of the Academy of Marketing Science, Vol. 27 No. 2, pp. 237.

Frazier, G. L., Gill, J. D., and Kale, S. H. (1989), "Dealer Dependence Levels and Reciprocal Actions in a Channel of Distribution in a Developing Country," American Marketing Association Journal of Marketing, pp. 50-59.

Gary D. (1990), "Marketing to Retailers: A Battle for Distribution?" Long Range Planning, Vol. 23 No. 6: 101-108.

Gerring. J. (2007) Case Study Research: Principles and Practices, Cambridge: Cambridge University Press.

Ghauri, D. K., Trivedi, M. \& Grewal, D. (2008), "Understanding the Determinants of Retail Strategy: An Empirical Analysis,” Journal of Retailing, Vol 84, pp. 256-267.

Ghoshal, S. (1987), “Global Strategy: An Organizing Framework," Strategic Management Journal, Vol. 8 (September-October), pp.42-50.

Gomes, E., Angwin, D.,Peter, E. and Mellahi, K. (2012) "HRM Issues and Outcomes in African Mergers and Acquisitions: A Study of the Nigerian Banking Sector." The International Journal of Human Resource Management, vol 23, no. 14 (July 2012), pp. 2874-2900.

Gomes, E., Cohen,M., and Mellahi. K., (2011) "When Two African Cultures Collide: A Study of Interactions between Managers in a Strategic Alliance between Two African Organizations." Journal of World Business, vol 46, no. 1 (January 2011), pp. 5-12. 
Harvey, M.G., Richey, R.G., 2001a. Global supply chain management The selection of globally competent managers. Journal of International Management 24.

Harvey, M.G., Richey, R.G., 2001b. Global supply chain management The selection of globally competent managers. Journal of International Management 24.

Hätönen, J., 2009. Making the locational choice. Journal of International Management 15, 61-76. https://doi.org/10.1016/j.intman.2008.06.003

Hutchinson, K., Quinn, B., and Alexander, N. (2006) "SME Retailer Internationalisation: Case Study Evidence from British Retailers.” International Marketing Review, vol 23, no. 1 (January 2006), pp. 25-53.

Hutchinson, K., Quinn, B., Alexander, N. \& Doherty A. M. (2009), "Retailer internationalization: overcoming barriers to expansion," The International Review of Retail, Distribution and Consumer Research, vol 19, no 3, pp. 251-272.

Hoskisson, R.E., Eden, L., Lau, C.M. and Wright, M. (2000), "Strategy in emerging economies", Academy of Management Journal, Vol. 43, pp. 249-67.

Ivory, S. B. and Brooks, S. B. (2017). Managing corporate sustainability with a paradoxical lens: Lessons from strategic agility. Journal of Business Ethics, (published online, ahead of print), DOI 10.1007/s10551-017-3583-6.

Jain, S.C. (1989), "Standardization of international marketing strategy: some research hypotheses," Journal of Marketing, Vol. 53, pp. 70-79.

Jamshed, S. (2014), "Qualitative research method-interviewing and observation," Journal of Basic and Clinical Pharmacy, Vol. 5 No. 4, pp. 87-88.

Johnston, K. (2009). Extending the marketing myopia concept to promote strategic agility. Journal of Strategic Marketing, Vol 17, no 2, 139-148.

Joia, L.A., Malheiros, R., 2009. Strategic alliances and the intellectual capital of firms. Jnl of Intellectual Capital 10, 539-558. https://doi.org/10.1108/14691930910996634

Junni, P., Sarala, R.M., Tarba, S.Y., Weber, Y., 2015. The Role of Strategic Agility in Acquisitions. British Journal of Management 26, 596-617. https://doi.org/10.1111/1467$\underline{8551.12115}$

Khanna, T. and Krishna, P. (1997), "Why Focused Strategies May Be Wrong for Emerging Markets," Harvard Business Review, Vol. 75 No. 4, pp. 41-51. 
Khoshnood, N.T. \& Nematizadeh, S. (2017), Strategic agility and its impact on the competitive capabilities in Iranian private banks, International Journal of Business and Management, Vol.12 No.2, pp220-229

Killough, J. (1978), "Improved payoffs from transnational advertising," Harvard Business Review, Vol. 56 July-August, pp. 102-110.

Kim, W., Hallsworth, A. \& Kim. H. (2018) On being local and being successful in Korea: Tesco and E-mart. Area

Kumar, V., Sunder, S., Sharmac, A. (2014), "Leveraging Distribution to Maximize Firm Performance in Emerging Markets," Journal of Retailing, Vol. 91 No. 4, pp. 627-643.

Lee, G. and Xia, W. (2010). Toward agile: An integrated analysis of quantitative and qualitative field data on software development agility. MIS Quarterly, vol 34, No 1, pp.87114.

Lee, J.Y., Park, Y.-R., Ghauri, P.N., Park, B.I., 2014. Innovative Knowledge Transfer Patterns of Group-Affiliated Companies: The effects on the Performance of Foreign Subsidiaries. Journal of International Management 107-123. https://doi.org/10.1016/j.intman.2013.04.002

Levitt, T. (1960), “Marketing Myopia,” Harvard Business Review, Vol. 60 July-August, pp. $45-56$.

Levitt, T. (1983), “The Globalization of Markets,” Harvard Business Review, Vol. 61: 92-102.

Liu, S., Perry, P., Moore, C. and Warnaby, G. (2016), "The standardization-localization dilemma of brand communications for luxury fashion retailers' internationalization into China," Journal of Business Research, vol 69, no 1, pp.357-364.

Liu, Y. and Vrontis, D. (2017), Emerging markets firms venturing into advanced economies: The role of context, Thunderbird International Business Review, Vol. 59, pp.255-261.

Liu, Y., Sarala, R.M., Xing, Y. \& Cooper, C.L. (2017), "Human Side of Collaborative Partnerships: A Microfoundational Perspective," Group \& Organization Management, Vol. 42, no 2, pp.151-162

Lu, Y. and Ramamurthy, K. R. (2011). Understanding the link between information technology capability and organizational agility: An empirical examination. MIS Quarterly, Vol.35, No. 4, pp. $931-954$. 
Loosveldt, G. and Beullens, K. (2013), "The impact of respondents and interviewers on interview speed in face-to-face interviews," Social Science Research, Vol. 42, pp. 1422-1430.

Mahajan, V. and Banga, K. (2006), "The 86\% Solution: How to Succeed in the Biggest Market Opportunity of the 21st Century", Wharton School Publishing: Pearson Education.

Martinez, C.A. \& Kalliny, M. (2012), "Academic research in the Latin American context: a review of the empirical literature 1990-2010," Multinational Business Review, vol 20, no 3, pp. 231-247.

Mbaye F. D. \& Seck, A. M. (2018), "How store service quality affects attitude toward store brands in emerging countries: Effects of brand cues and the cultural context," Journal of Business Research, Vol. 86, pp. 311-320.

Mellahi, K., Mehmet, D., Cavusgil, S.T., and Wade, D. (2010), "Marketing strategies of MNCs from emerging markets: internationalisation and market entry mode," International Marketing Review, Vol. 27 No. 3, pp. 1-6.

Michell, P., Lynch, J., \& Alabdali, O. (1998), "New perspective on marketing mix program standardization”, International Business Review, Vol. 7, pp. 617-634.

Miles,M.,Huberman, A.M. \& Saldana, J.(2014), Data Analysis: A Methods Sourcebook, Edition 3. Thousand Oaks, California: SAGE

Mohr, A. \& Batsakis, G. (2018), "Firm resources, cultural distance and simultaneous international expansion in the retail sector" International Business Review, Vol 27, no 1, pp.113-124.

Mouton, J. (1996), Understanding Social Research, Pretoria: Van Schaik Publishers.

Morscher, C., 2015. Book Review. Journal of International Management 21, 211-213. https://doi.org/10.1016/j.intman.2015.03.001

Mukherjee, J., and Basu, A. (2010), "Nestlé India Management Case: Distributor Sales Force Performance Management," The Journal of Business Perspective, Vol. 14 No. 4 (OctoberDecember), pp. 309-321. 
Murray, J.Y., Ju, M., and Gao, G.Y., (2012), "Foreign market entry timing revisited: trade-off between market share performance and firm survival", Journal of International Marketing, Vol. 20 No. 3, pp. 50-64.

Nadayama, N., 2019. Isolated Foreign Subsidiary's Initiative in Knowledge Transfer Within the MNE. Journal of International Management 25, 100652.

Nandonde, F., A. \& Kuada. J. (2016), "International firms in Africa's food retail businessemerging issues and research agenda," International Journal of Retail \& Distribution Management, vol 44, No 4, pp. 448-464.

Ojha, D. (2008), Impact of strategic agility on capabilities and financial performance (unpublished doctoral Dissertation). School of Clemson University, south Carolina, United States

Onkvisit, S., and Shaw, J. J. (1990), "Global advertising: revolution or myopia?" Journal of International Consumer Marketing, Vol. 2 No. 3, pp. 97-111.

Ozsomer, A., Bodur, M., and Cavusgil, S. T. (1991). "Marketing standardization by multinationals in an emerging market," European Journal of Marketing, Vol. 25 No. 12, pp. $50-64$.

Pereira, V., Mellahi, K., Temouri, Y., Patnaik, S., Roohanifar, M., 2018. Investigating dynamic capabilities, agility and knowledge management within EMNEs- longitudinal evidence from Europe. Journal of Knowledge Management. https://doi.org/10.1108/JKM-06-2018-0391

Pfeiffer, C. (2016),'These are the '10 emerging markets of the future”, Business Insider, July

Poulis, K., Poulis, E. and Plakoyiannaki, E. (2013), "The Role of Context in Case Study Selection: An International Business Perspective." International Business Review 22, no. 1, pp. 304-14.

Piercy, N. F., Low, George S., \& Cravens, D. W. (2004), "Examining the effectiveness of sales management control practices in developing countries," Journal of World Business, vo 39, no 3, pp. 255-267.

Paddison, A., and Calderwood, E. (2007). "Rural Retailing: A Sector in Decline", International Journal of Retail and Distribution Management, Vol. 35 No. 2, pp. 136-155.

Prahalad, C.K. (2006), "The Fortune at the Bottom of the Pyramid," Pearson: New Jersey. 
Putzhammer, M., Slangen, A., Puck, J., Lindner, T., 2019. Multinational firms' pace of expansion within host countries: How high rates of pro-market reform hamper the local exploitation of foreign expansion knowledge. Journal of International Management 100703. https://doi.org/10.1016/j.intman.2019.100703

Quelch, J. A. and Hoff, E.J. (1986), "Customizing Global Marketing," Harvard Business Review, Vol. 64 (May-June), pp. 59-68.

Quester, P.G., and Conduit, J. (1996), "Standardization, centralization and marketing in multinational companies," International Business Review, Vol. 5 No. 4, pp. 395-421.

Rao-Nicholson, R., and Khan, Z.(2017), "Standardization versus adaptation of global marketing strategies in emerging market cross-border acquisitions", International Marketing Review, Vol. 34 No. 1, pp.138-158.

Rees, C., \& Edwards, T. (2009), "Management strategy and HR in international mergers: choice, constraint and pragmatism," Human Resource Management Journal, vol 19, no 1, pp. 24-39

Rong, K., Wu, J., Shi, Y., Guo, L., 2015. Nurturing business ecosystems for growth in a foreign market: Incubating, identifying and integrating stakeholders. Journal of International Management 21, 293-308. https://doi.org/10.1016/j.intman.2015.07.004

Rosen, B. N. (1990), “Global products: when do they make strategic sense?" Advances in International Marketing, Vol. 4, pp. 57-71.

Rugman, Alan M., and Verbeke, A. (2001), "Subsidiary-Specific Advantages in Multinational Enterprises,” Strategic Management Journal, Vol. 22, No. 3, pp. 237-250.

Rugman, Alan M., Hoon Oh, C., and Lim, Dominic S. K. (2012), "The regional and global competitiveness of multinational firms", Journal of the Academy of Marketing Sciences, No. 40 , pp. 218-235.

Ruschton, A., Croucher, P., Baker, P. (2014), "The handbook of Logistics and Distribution Management", Kogan Page Limited, $5^{\text {th }}$ Edition, pp. 52-86. 
Rylander, A., Peppard, J., 2003. From implementing strategy to embodying strategy: Linking strategy, identity and intellectual capital. Jnl of Intellectual Capital 4, 316-331. https://doi.org/10.1108/14691930310487789

Samiee, S. (1993), "Retailing and Channel Considerations in Developing Countries: A Review and Research Propositions," Journal of Business Research, Vol. 27, pp. 103-130.

Sethi, D., Guisinger, S., 2002. Liability of foreignness to competitive advantage: How multinational enterprises cope with the international business environment. Journal of International Management 18.

Shams, S.M.R. (2016). Capacity building for sustained competitive advantage: a conceptual Framework. Marketing Intelligence \& Planning, 34 (5), 671-691.

Sinha, M. and Sheth, J., 2017. Growing the pie in emerging markets: Marketing strategies for increasing the ratio of non-users to users. Journal of Business Research

Sheth, J. N. (2011), "Impact of Emerging Markets on Marketing: Rethinking Existing Perspectives and Practices," Journal of Marketing, Vol. 75 No. 4, pp. 166-182.

Sinkovics, R., Penz, E., and Ghauri.P. N. (2008) "Enhancing the Trustworthiness of Qualitative Research in International Business." MIR: Management International Review 48, no. 6 (2008): pp. 689-713.

Sorenson, R. Z. and Wiechmann, U. E. (1975), "How Multinationals View Marketing Standardization," Harvard Business Review, Vol. 53 (May-June), pp. 38.

Spiggle, S. (1994), "Analysis and interpretation of qualitative data in consumer research", Journal of Consumer Research, Vol. 21, pp. 491-503.

Spiggle, S. (1998), "Creating the frame and the narrative," in Representing Consumers: Voices, Views and Visions, ed. B.Stern, New York: Rouledge, pp.156-190

Stem, L. W. and Sturdivant, F. D. (1987), "Customer-Driven Distribution Systems," Harvard Business Review, August, p. 34.

Surdu, I., Mellahi, K., \& Glaister, K (2018), “Emerging market multinationals' international equity-based entry mode strategies" International Marketing Review, Vol 35, No 2, pp.342359. 
Szymanski, D. M., Bharadwaj, S. G., Varadarajan, P. R. (1993), "Standardization versus Adaptation of International Marketing Strategy: An empirical Investigation," Journal of Marketing, Vol. 57 (October), pp. 1-17.

Tan Q. and Sousa C. (2013), "International Marketing Standardization - A Meta-Analytic Examination of its Antecedents and Consequences," Management International Review, Vol. 53, No. 5, pp. 711-739.

Tasavori, M., Ghauri, P. N., \& Zaefarian, R. (2016), "Entering the base of the pyramid market in India: A corporate social entrepreneurship perspective," International Marketing Review, Vol. 33 Issue 4, pp. 555-579.

Teece, D., Peteraf, M., Leih, S., 2016. Dynamic Capabilities and Organizational Agility: Risak, uncertainty, and strategy in the innovation economy. California Management Review 58, $13-$ 36. https://doi.org/10.1525/cmr.2016.58.4.13

Teegen, H., 1998. Authority and trust in cross border partnerships: Mexican firm perspectives. Journal of International Management 17.

Terpstra, V. and Sarathy, R. (2000), International marketing, UK: The Dryden Press.

Thakur, R. (2015), "Community marketing: serving the base of the economic pyramid sustainably," Journal of Business Strategy, Vol. 36 No. 4, pp. 40-47.

Theodosiou, M. and Leonidou, L.C. (2003), "Standardization versus adaptation of international marketing strategy: an integrative assessment of the empirical research," International Business Review, Vol. 12, pp. 141-171.

Valero, J., Carlos, N. and Dubey, A. (2010), "Getting routes to market right. Designing profitable go-to-market models in consumer goods", Booz and Company, pp. 3-15.

Vargo, S. L. and Lusch, R. F. (2004), "Evolving to a new dominant logic for marketing," Journal of Marketing, Vol. 68 No. 1, pp. 1-23.

Vendrell-Herrero, F., Gomes, E., Mellahi, K., and Child, J. (2017), "Building international business bridges in geographically isolated areas: the role of foreign market focus and outward looking competences in Latin American SMEs", Journal of World Business, Vol 52, pp 489502 
Venugopal, P. (2012), "Urban Orientation of Rural Consumers: Implication for Consumer Goods Distribution,” International Journal of Rural Management, Vol. 8 No. 1\&2, pp. 107119.

Volberda, Henk W. (1996), "Toward the Flexible Form: How to Remain Vital in Hypercompetitive Environments," Organization Science, Vol. 7, No. 4, pp. 359-374.

Vrontis, D., Thrassou, A., Lamprianou, I., (2009), "International marketing adaptation versus standardisation of multinational companies," International Marketing Review, Vol. 26 No. 4/5, pp. 477-500.

Walters, P.G.P. (1986), "International Marketing Policy: A Discussion of the Standardization Construct and its Relevance for Corporate Policy," Journal of International Business Studies, 17, pp. 55-69.

Walters, P.G.P., and Toyne, B. (1989), "Product modification and standardization in international markets: strategic options and facilitating policies," Columbia Journal of World Business, 14, pp. 37-44.

Webb, K. L., 2002. Managing Channels of Distribution in the Age of Electronic Commerce. Industrial Marketing Management 31(2), 95 - 102.

Weber, Y.\& Tarba, S. Y., 2014. Strategic Agility: A State of the Art introduction to the special section on strategic agility. California Management Review 56 (3): 5-13. https://doi.org/10.1525/cmr.2014.56.3.5.

Welch, C. "The Archaeology of Business Networks: The Use of Archival Records in Case Study Research.” Journal of Strategic Marketing 8, no. 2 (June 2000): 197-208.

Welch, C., Piekkari, R., Plakoyiannaki, E. and Paavilainen-Mäntymäki, E. (2011), "Theorising from case studies: towards a pluralist future for international business research", Journal of International Business Studies, Vol. 42 No. 5, pp. 740-762

Welsh, D., H, B., Alon, I. and Falbe, C.M. (2006), “An examination of international retail franchasing in emerging markets", Journal of Small Business Management, Vol. 44, pp. 13049.

Whitelock, J. M., \& Pimblett, C. (1997), "The standardization debate in international marketing," Journal of Global Marketing, Vol. 10 No. 3, pp. 45-66. 
Wills, J. A., Samli, C., and Jacobs, L. (1991), "Developing Global Products and Marketing Strategies: A Construct and Research Agenda," Journal of Academy of Marketing Science, Vol. 19, pp. 1-10.

Wind, Y. (1986), “The myth of globalization,” Journal of Consumer Marketing, Vol. 3 No. 2, pp. 23-26.

Yip, G. S. (1989). "Global Strategy in a World of Nations," Sloan Management Review, Vol. 31 No. 1, pp. 29-41.

Zhang, J., Farris, P.W., Irvin, J. W., Kushwaha, T., Steeburgh, T. J., \& Weitz, B. A. (2010), "Crafting Integrated Multichannel Retailing Strategies," Journal of Interactive Marketing, Vol. 24 No. 2, pp. 168-80.

Zook, C. and Allen, J. (2011), "The Great Repeatable Business Model," Harvard Business Review, Vol. 89 No. 11, pp. 106-114. 